The first preprint version posted on OSF preprints (July 26, 2021). The published version of this preprint is available at [https://www.mdpi.com/20734425/13/5/719] Citation: Domazet-Lošo, T. mRNA Vaccines: Why Is the Biology of Retroposition Ignored? Genes 2022, 13, 719. https://doi.org/10.3390/genes13050719

\section{mRNA Vaccines: Why Is the Biology of Retroposition Ignored?}

Tomislav Domazet-Lošo ${ }^{1,2}$

${ }^{1}$ Laboratory of Evolutionary Genetics, Division of Molecular Biology, Ruđer Bošković Institute, Bijenička cesta 54, HR-10000 Zagreb, Croatia; tdomazet@irb.hr ${ }^{2}$ School of Medicine, Catholic University of Croatia, Ilica 242, HR-10000 Zagreb, Croatia
Keywords: mRNA vaccines; retroposition; L1 elements; LINE-1; retrotransposons; retrocopy; parental genes; genome integration; insertional mutagenesis

several others are under development [3-5]. It was often suggested that the main advantage of mRNA-based 36 
The first preprint version posted on OSF preprints (July 26, 2021). The published version of this preprint is available at [https://www.mdpi.com/20734425/13/5/719] Citation: Domazet-Lošo, T. mRNA Vaccines: Why Is the Biology of Retroposition Ignored? Genes 2022, 13, 719. https://doi.org/10.3390/genes13050719

vaccines, compared to the more conventional approaches is the possibility of their rapid development and large-scale deployment [6,7], which are both desirable properties in pandemic situations. The statement that vaccine mRNAs do not pose a risk for genome integration, e.g., [6,8-12], and consequently, that there is no insertional mutagenesis risk, is another commonly listed advantage of mRNA-based vaccines, especially when contrasted with the safety profile of DNA-based therapeutics $[10,12,13]$. This claim prompted me to look more carefully into the mRNA vaccine literature to find a rationale for it. Surprisingly, I was not able to track down any experimental or theoretical study that specifically addresses the possibility of genome integration of mRNA therapeutics.

This shortage of relevant studies is reflected in numerous reviews [4-6,9,10,14-18], book chapters on the mRNA vaccines [13,19-22] and documents of international organizations [23-25], which often state that mRNA vaccines do not pose the risk for genome integration but do not cite any references in support of this idea. Occasionally, some citations are embedded, e.g., [15,22,26,27], but unfortunately, they are circular as they point to similar unsupported statements $[6,10,21,28-30]$. This signals that the idea of vaccine mRNA's resistance to genome integration behaves like a meme that self-replicates in the literature and, therefore, it should not be considered reliable scientific information. Undoubtedly, there is always a possibility that my literature search missed some important work; however, other researchers also notice, although without going into details, the shortage of studies that explicitly deal with the possibility of vaccine mRNA genome integration [13,31-34]. In the absence of such studies, statements such as "In addition, IVT mRNA-based therapeutics, unlike plasmid DNA and viral vectors, do not integrate into the genome and therefore do not pose the risk of insertional mutagenesis." [10], "First, safety: as mRNA is a non-infectious, non-integrating platform, there is no potential risk of infection or insertional mutagenesis." [6] or "mRNA-based vaccines avoid the risk of integration with the host cell genome ..." $[24,25]$ obviously go against sound scientific epistemology.

Besides the lack of references, the argumentation line for the claim that the genome integration of vaccine mRNA molecules is not possible, or is negligible, is rather limited in the vast majority of papers. Many of them simply state that vaccine mRNA cannot integrate into the host genome without explaining why this is not possible $[3,10,12,19-22,26,30]$. Others shortly describe that vaccine mRNAs remain in the cytoplasm of the host cells - in contrast to DNA-based vaccines, which must enter the nucleus to be effective - and thus do not have the opportunity to change the genome [4,9,18,27,35].

Recently, some papers argued that the relatively short persistence of mRNA makes genome integration of mRNA vaccines improbable $[4,13,27]$. However, some of them also recognize the possibility of genome integration if vaccine mRNA is reverse-transcribed in the host cells [4,13,31]. Although human endogenous retroviruses (HERVs) and retroviral infections (e.g., HIV) are mentioned as a possible source of enzymes for reverse transcription and genome integration, the common conclusion is that the integration risk is still highly unlikely [4,31]. In contrast, some authors are more cautious and suggest that investigation may be needed to clarify whether vaccine mRNA integration can occur [13]. 
The first preprint version posted on OSF preprints (July 26, 2021). The published version of this preprint is available at [https://www.mdpi.com/20734425/13/5/719] Citation: Domazet-Lošo, T. mRNA Vaccines: Why Is the Biology of Retroposition lgnored? Genes 2022, 13, 719. https://doi.org/10.3390/genes13050719

\section{The Biology of Retroposition}

Nevertheless, this discussion within the vaccinology field on the vaccine mRNA genome integration risks is rather brief and surprisingly incomplete, as it does not consider the accumulated knowledge on the biology of retroposition [36-40]. In many eukaryotes, the cellular mRNAs of various genes are endogenously reverse76 transcribed and reintegrated into the genome, yielding their retrocopies (Figure 1B) [36,38-40]. This process of mRNA-mediated gene duplication is highly frequent in therian mammals [41] and is best studied in primates RNA viruses (bornaviruses) is also reported $[42,43]$. Of note, the term retrocopy is often interchanged with other related terms, such as processed pseudogenes, retrotransposed pseudogenes, retropseudogenes, retroposed gene copies, retroCNVs and retrogenes, as the terminology related to retroposition is not yet fully settled [38,39]. 
The first preprint version posted on OSF preprints (July 26, 2021). The published version of this preprint is available at [https://www.mdpi.com/20734425/13/5/719] Citation: Domazet-Lošo, T. mRNA Vaccines: Why Is the Biology of Retroposition lgnored? Genes 2022, 13, 719. https://doi.org/10.3390/genes 13050719

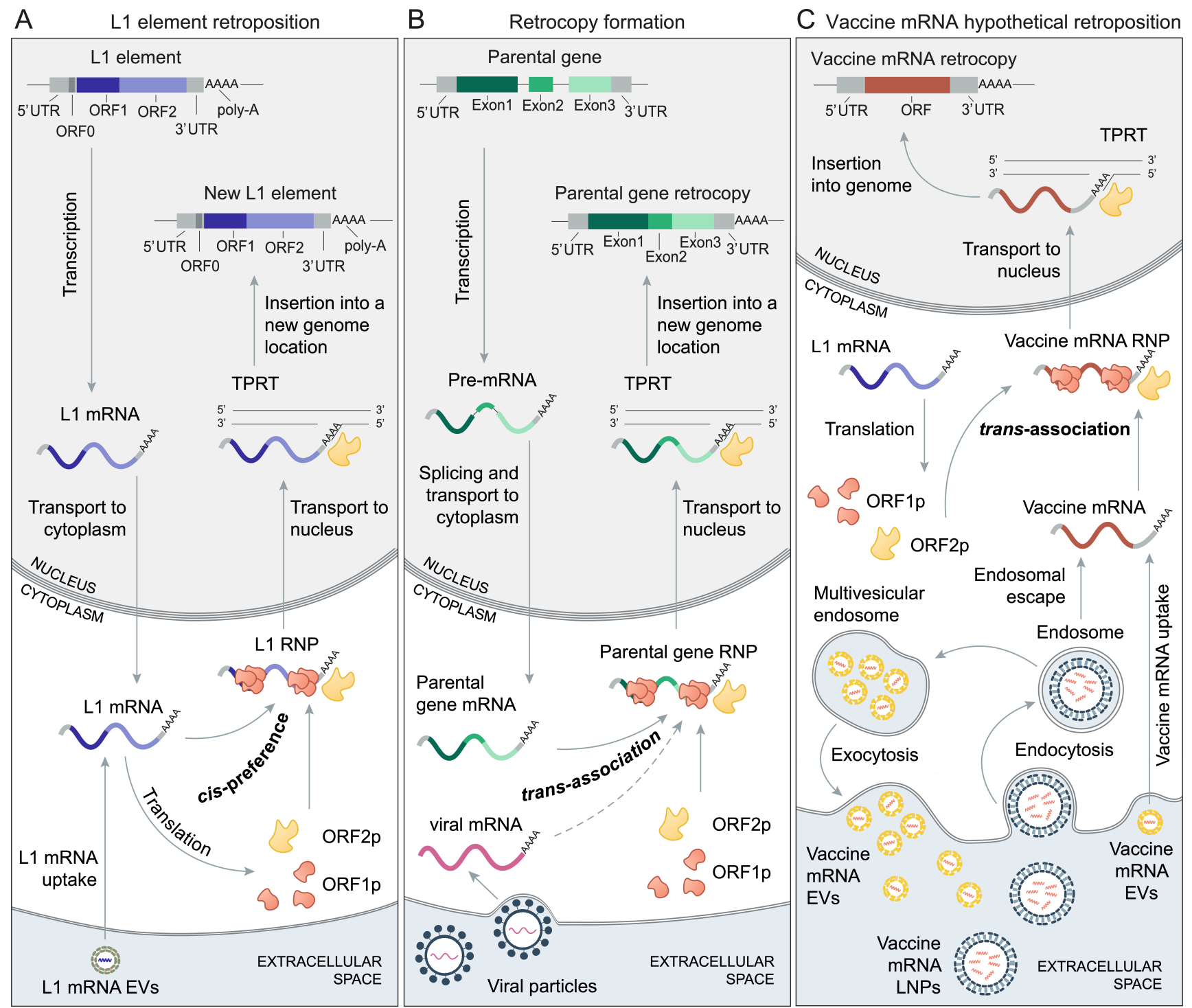

Figure 1. L1-mediated retroposition. (A) Retroposition cycle of L1 elements. An active L1 element is transcribed in the nucleus and the resulting L1 mRNA is transported to the cytoplasm where it undergoes translation $[44,45]$. L1 mRNA codes for ORF1 and ORF2 proteins, which preferentially associate with L1 mRNA (cis-preference) to form L1 ribonucleoprotein particle (L1 RNP) [44-46]. ORF1p is an RNA binding protein with chaperone activity, while ORF2p functions as reverse transcriptase and endonuclease $[47,48]$. By a yet unresolved mechanism, L1 RNP, which contains at least L1 mRNA and ORF2p, enters the nucleus. In the nucleus, L1 mRNA is reverse-transcribed and integrated into the genome via the process of target-primed reverse transcription (TPRT) [45,47-49]. The retroposition mechanism relies on the binding of ORF2p to the L1 mRNA poly-A tail [48,50-52]. There is some evidence that the cells could uptake extracellular vesicles (EVs) containing L1 mRNA, which can then undergo translation and retroposition [53]. (B) L1-mediated retroposition of endogenous coding genes and L1-mediated retroposition of viral mRNAs. A parental protein- 
The first preprint version posted on OSF preprints (July 26, 2021). The published version of this preprint is available at [https://www.mdpi.com/20734425/13/5/719] Citation: Domazet-Lošo, T. mRNA Vaccines: Why Is the Biology of Retroposition Ignored? Genes 2022, 13, 719. https://doi.org/10.3390/genes13050719

coding gene is transcribed in the nucleus. The resulting pre-mRNA is processed and mature parental gene mRNA is then transported to the cytoplasm. L1 proteins (ORF1p and ORF2p) interact with parental gene mRNA via the process termed trans-association to form a parental gene ribonucleoprotein particle (parental gene RNP) [36,45,46,49]. Similar to L1 RNP, a parental gene RNP enters the nucleus where the parental gene mRNA, through TPRT, is reverse-transcribed and integrated into the genome. The poly-A tail of parental gene mRNA plays a crucial role in this process [36,50-52]. By a similar process, mRNA molecules that stem from non-retroviral RNA viruses could be integrated into the genome. Examples include the integration of mRNAs from bornaviruses [42,43] and probably coronaviruses [54,55]. (C) Hypothetical L1-mediated retroposition of vaccine mRNA. Vaccine mRNA formulated in lipid nanoparticles (LNPs) enter the cell via endocytosis $[1,2,6,10,56]$. A fraction of the vaccine mRNA enters the cytosol via endosomal escape, while the rest of the vaccine mRNA undergoes degradation in endosomes [56] or is repackaged in multivesicular endosomes into extracellular vesicles (EVs) and secreted back into the extracellular space [57]. The neighboring or distant cells can uptake vaccine mRNA from these EVs [57,58]. L1 proteins (ORF1p and ORF2p) interact with vaccine mRNA via a process termed trans-association to form a vaccine mRNA ribonucleoprotein particle (vaccine mRNA RNP) [36,45,46,49]. Like L1 and parental gene RNPs, a vaccine mRNA RNP enters the nucleus where the vaccine mRNA, through TPRT, is reverse-transcribed and integrated into the genome. The poly-A tail of vaccine mRNA plays a crucial role in this process [36,50-52].

Depending on the annotation methodology, the estimated number of retrocopies in the human genome varies, 115 but the figures in most studies are approximately 8000 [38,39,59,60]; these retrocopies are derived from around 2500 parental genes [59,61], i.e., genes whose mRNAs are reverse-transcribed and integrated into the genome (Figure 1A,B). These values are similarly high in all screened therian mammals and reflect endogenous retroposition activity during the $\sim 200$ My of their evolution [41,61]. However, the continuous activity of retroposition is also apparent in extant human populations, where substantial polymorphism of novel retrocopies is revealed [37,60,62-64]. For instance, it was estimated that an individual harbors on average six novel retrocopies that are absent from the human reference genome, and that these retrocopies were derived from the pool of 503 unique parental genes [37]. These values indicate a rather high retroposition activity in present human populations.

A recent study in mice suggested that the actual rate of retrocopy generation in extant populations is even higher and possibly similar between humans and mice [40], and hence, it is not surprising that retrocopy variation is detected in medical contexts $[65,66]$. However, it is also suggested that due to the use of unoptimized analytical pipelines, many retrocopies have often been overlooked in routine genetic testing $[40,65]$. At present, there are several documented cases of retrocopy emergence related to diseases in animals $[49,65,67]$, and one case of pathogenic retrocopy in humans $[49,65,68,69]$, but more could potentially be discovered [40]. Actually, it seems that retrocopy variation in human populations might be more phenotypically relevant and population-specific than single nucleotide polymorphisms [37,40] and that most 
The first preprint version posted on OSF preprints (July 26, 2021). The published version of this preprint is available at [https://www.mdpi.com/20734425/13/5/719] Citation: Domazet-Lošo, T. mRNA Vaccines: Why Is the Biology of Retroposition Ignored? Genes 2022, 13, 719. https://doi.org/10.3390/genes13050719

newly transposed retrocopies have a deleterious impact [40]. All of this suggests that the mutation load coming from the retroposition activity in extant human populations is medically relevant.

Regardless of the initial selective purge [40], retrocopies are a source of novel genes with adaptive significance that contribute to human biology and health [36,39]. Retrocopies have been viewed as the unfunctional 136 remnants of evolutionary turnover, termed processed pseudogenes [39], mainly because it was presumed that 137 retrocopies inherently lack transcription-driving elements and, thus, could not be transcribed [39-41]. A 138 similar argument is recently raised in the vaccinology field when the possibility of vaccine mRNA genome integration and its impact on phenotypes is discussed [13]. However, after it was realized that most regions of a mammalian genome are transcribed [70-72] and that retrocopies could easily gain their own regulatory elements $[36,38,40,41]$, it has become apparent that most retrocopies show evidence of transcription $[38,40,41]$.

These transcribed retrocopies are thus the source of evolutionary innovations, as they could be further transformed into novel protein-coding or RNA retrogenes [36,38,41,73]. Approximately several hundred RNA and several hundred protein-coding retrogenes are estimated to be active in humans and mice [36,38]. For most of them, the functional significance has yet to be determined, but some are known to be human disease genes [74-76] or to have discernible phenotypes [36,38].

Many of the retrocopies I have discussed so far are vertically transmitted through the germline, but mRNA retroposition also occurs in somatic tissues. Somatic retroposition is substantially less studied, but it is known to be common in cancer tissues [62,77-80] and to occur during early development $[68,69]$. However, the activity of endogenous retroelements that drive retroduplication in humans suggests that mRNA retroposition events should be found in other somatic tissues as well (see below). This indicates that retrocopies continuously reshape the human genome, not only at the population level and deeper evolutionary time scale but also in somatic tissues during individual development. It is therefore important to consider the endogenous drivers of retroposition in humans when the probability of vaccine mRNA genomic integration is evaluated.

\section{The Mechanisms of Retrocopy Formation}

The mechanism that leads to the formation of retrocopies in a human lineage is relatively well studied and predominantly includes long interspersed element-1 (LINE-1 or L1, Figure 1A) retrotransposons $[36,38,40,46,81]$, albeit there is some evidence that retroposition through long terminal repeat (LTR) retrotransposons is also possible [38,81]. However, very surprising quotes such as "The only known mechanism by which RNA can integrate into the host genome is in the presence of a retrovirus particle containing reverse transcriptase." [23] reveal that the vaccinology field, for an unclear reason, is unaware of the existence and significance of L1-driven retroposition in humans. To bridge this gap between the fields, and to set the stage for the discussion on the possibility of vaccine mRNA retroposition, I first provide here an overview of the L1-dependent retroposition mechanism. 
The first preprint version posted on OSF preprints (July 26, 2021). The published version of this preprint is available at [https://www.mdpi.com/20734425/13/5/719] Citation: Domazet-Lošo, T. mRNA Vaccines: Why Is the Biology of Retroposition Ignored? Genes 2022, 13, 719. https://doi.org/10.3390/genes13050719

L1 retroelements are around $6 \mathrm{~kb}$ long, make up 17 percent of the human genome and around one hundred of them are active in spreading their copies in the genome by means of retroposition of their own mRNA (Figure 1A) $[44,45,49,82-85]$. When transcribed, $L 1$ produces bicistronic mRNA that codes for two proteins: ORF1p is an RNA binding protein with chaperone activity, while ORF2p functions as reverse transcriptase and endonuclease [44,45,47-49,84,85]. Together with an L1 mRNA, these proteins assemble in the cytoplasm into 171 an L1 ribonucleoprotein particle (L1 RNP), which can then enter the nucleus (Figure 1A) [44,45,47-49,84,85]. 172 In the nucleus, L1 mRNA is eventually reverse-transcribed and integrated into the genome at A/T-rich consensus target sites via the process termed target-primed reverse transcription (TPRT) (Figure 1A) [45,4749]. In the antisense direction, $L 1$ also codes for ORF0p, which is a small peptide that localizes in the nucleus and enhances the efficiency of retrotransposition $[49,86]$. During the L1 lifecycle, diverse host proteins interact with L1 RNPs via promoting or suppressing their retrotransposition $[49,87]$. The L1 protein machinery preferentially targets their encoding mRNA (cis-preference), but it can also mobilize a variety of other RNAs present in the cell (trans-association), including non-autonomous mobile elements (Alu, SVA), splicesomal RNAs and diverse protein-coding mRNAs (Figure 1B) $[45,46,49,83,88]$.

This relaxed retroposition behavior of L1 elements, which allows for the mobilization of various mRNAs through trans-association, is responsible for the massive accumulation of non-autonomous mobile elements and retrocopies in genomes (Figure 1B). The question arises regarding how L1 elements achieve such promiscuous performance. The underlying reason for such behavior is linked to the L1 retroposition mechanism that is contingent on ORF2p binding to the poly-A tail during RNP formation in the cytoplasm (Figure 1) [50,51]. Subsequently in the nucleus, genome integration also relies on the poly-A tail, which permits flexibility in DNA priming at the target site during the TPRT process [48,52]. Given that poly-A tails are unspecific low-complexity sequences that are almost ubiquitously present at the $3^{\prime}$ ends of cellular mRNAs [89], this implies that, in principle, every mRNA could be a target of L1 protein machinery and undergo the TPRT process (Figure 1C).

However, the complete lack of retroposition specificity would significantly lower the fitness of L1 elements and compromise their parasitic proliferation in the genomes. To avoid this scenario, L1 elements managed to preferentially target their own mRNA, regardless of the poly-A tail dependence [46,90,91]. A popular model that tries to explain the mechanisms of this cis-preference envisages that, during translation, emerging L1 proteins associate immediately with their encoding mRNA at the ribosome $[44,47,50,92]$. Obviously, this or a similar process ensures the balance between the parasitic reproduction of L1 elements and the occasional mobilization of diverse mRNAs by trans-association via poly-A tracts (Figure 1).

\section{L1 Elements in Germline and Soma}

The possibility of vaccine mRNA integration and its resulting phenotypic consequences highly depend on the 201 overall dynamics of L1 retroelements in the human body, which is a topic that I consider in this section. 
The first preprint version posted on OSF preprints (July 26, 2021). The published version of this preprint is available at [https://www.mdpi.com/20734425/13/5/719] Citation: Domazet-Lošo, T. mRNA Vaccines: Why Is the Biology of Retroposition Ignored? Genes 2022, 13, 719. https://doi.org/10.3390/genes13050719

L1 activity is an important contributor to genetic variation within and between individuals with implications for evolution and disease in humans $[45,85,93]$. Interaction between the host genome and L1 elements is multilayered with beneficial and detrimental effects on the host fitness [93-98]. For this reason, the host cells evolved various mechanisms to keep their activity in balance [93,96,99-104]. Regardless of these host protection mechanisms, a new retroposition event mediated by L1 elements must occur in the germline to be passed to the next generation [97].

The mere presence of numerous vertically inherited L1 elements, non-autonomous mobile elements and retrocopies in human genomes provides direct evidence that their mobilization repeatedly occurs in the germline [99]. It was also well established that L1 activity contributes to ongoing germline mutagenesis $[105,106]$. However, the precise dynamics of retroposition during the germline lifecycle are less clear $[96,97,107,108]$. The current data suggest that L1 elements show expression and retroposition activity in testes [96,105,106,109], spermatozoa [110,111], ovaries [105,106], oocytes [112] and early embryos $[97,99,105,107,108,113]$.

Although it was initially thought that L1 elements are mainly active in the germline, accumulated evidence suggests that they also should be considered an endogenous mutagen in somatic tissues [99,100,106,114]. L1 elements are expressed in diverse human somatic tissues, including liver, spleen, adrenal glands, lungs, heart and brain [106]; lymphoblastoid cell lines [115]; platelets; megakaryocyte; and T cells [98]. Expression and retroposition activity of L1 elements was detected in vascular endothelial cells as well $[109,116]$. However, somatic L1 retroposition has been extensively studied only in the brain, cancer tissues and the gastrointestinal tract $[45,78]$.

During both embryonic and adult neurogenesis, L1 retroposition activity generates significant neuronal mosaicism [60,99,117-121], which further increases in neurological disorders [121,122]. L1 retroposition occurs in diverse cell types of the central nervous system, including glial cells, neuronal progenitor cells, differentiating neurons and mature non-dividing neurons [118,121,123-126]. It is speculated that L1-driven somatic mosaicism may alter the functional properties of neural cells and that many of them may contain a unique genome $[118,126]$. However, the biological and medical significance of this mosaicism is not fully clear [120-122].

L1 elements are also highly expressed in many human cancers, where they function as an endogenous mutagen and can be responsible for driving mutations in tumorigenesis [84,85]. Epithelial cancers seem to be particularly prone to L1 retroposition [45,78]. Interestingly, L1 insertions are found in tumor cells, as well as normal cells of liver, stomach, colon and esophagus [127-130], suggesting widespread somatic activity of L1 elements in the gastrointestinal tract. In general, somatic L1 retroposition is highly ontogeny dependent and strongly increases with advanced age due to L1 transcriptional derepression [104,131]. In addition to endogenous regulation, the activity of L1 elements is sensitive to exogenous signals and could be induced by numerous environmental factors $[93,99,100,114,122]$. Taken together, it is clear that human germinative and 
The first preprint version posted on OSF preprints (July 26, 2021). The published version of this preprint is available at [https://www.mdpi.com/20734425/13/5/719] Citation: Domazet-Lošo, T. mRNA Vaccines: Why Is the Biology of Retroposition Ignored? Genes 2022, 13, 719. https://doi.org/10.3390/genes13050719

many somatic cells have a lasting potential for L1-mediated retroposition via cis-preference and transassociation (Figure 1).

\section{Vaccine mRNAs and Retroposition}

Evidently, various mRNAs in humans could be reverse-transcribed and integrated into the genome via L1 retroelements with negative effects on fitness. However, this does not readily imply that this will occur to vaccine mRNAs. A definitive answer will come from experiments and population monitoring, but for now, it is helpful to consider their described properties and evaluate them against the L1 retroposition mechanism (Figure 1). The active substance of the BNT162b2 vaccine is a 4284-nucleotide-long synthetic mRNA molecule that contains N1-methylpseudouridine (m1 occurring uridine $[1,132,133]$. This nucleoside modification reduces the innate immune response to exogenous mRNA molecules and enhances their translation (Table 1) [6,134-136]. Structurally, BNT162b2 mRNA consists of a 5' cap analog, a 5' untranslated region, a codon-optimized SARS-CoV-2 spike-protein-coding sequence, a 3' untranslated region and a 110-nucleotide poly-A tail [1,56,132,133]. These structural elements follow the usual eukaryotic mRNA architecture and help to increase RNA stability and translational efficiency of mRNA vaccines (Table 1) $[6,10,28,133]$. In contrast to BNT162b2, the exact mRNA sequence of the mRNA-1273 vaccine seems not to be publicly disclosed [56]. However, its general design is similar to BNT162b2 mRNA, including the use of $\mathrm{m} 1 \Psi$ instead of uridine, the presence of a $5^{\prime}$ cap structure, a $5^{\prime}$ untranslated region, a codon-optimized spike-protein-coding sequence, a $3^{\prime}$ untranslated region and a poly-A tail $[2,137]$.

Table 1. The list of factors that increase the possibility of vaccine mRNA retroposition by L1 elements.

\begin{tabular}{|c|c|}
\hline mRNA Vaccine Features & References $^{1}$ \\
\hline Native mRNA architecture & {$[6,10,28,133]$} \\
\hline $3^{\prime}$ poly-A tail & {$[51,52,132]$} \\
\hline $\mathrm{m} 1 \Psi$ modification & {$[20,134-136]$} \\
\hline Improved stability, half-life and translational efficiency & $\begin{array}{l}{[6,10,27,56,133,138,139} \\
]\end{array}$ \\
\hline mRNA concentration per dose & {$[1,140]$} \\
\hline Recurrent application & {$[1,2,56,141,142]$} \\
\hline Lipid nanoparticle formulation & {$[1,2,10,56,143]$} \\
\hline Cytosol delivery & {$[5,6,10,56]$} \\
\hline Biodistribution & {$[1,2]$} \\
\hline Extracellular vesicles repackaging & {$[53,57]$} \\
\hline Other Factors & References $^{1}$ \\
\hline Increased cell proliferation rates & {$[37,64,84]$} \\
\hline Aging & {$[104,131]$} \\
\hline Viral infection & {$[54,55,144-146]$} \\
\hline
\end{tabular}

${ }^{1}$ Some of the relevant references that describe these factors. For a full discussion, see the main text. 
The first preprint version posted on OSF preprints (July 26, 2021). The published version of this preprint is available at [https://www.mdpi.com/20734425/13/5/719] Citation: Domazet-Lošo, T. mRNA Vaccines: Why Is the Biology of Retroposition Ignored? Genes 2022, 13, 719. https://doi.org/10.3390/genes13050719

From the perspective of their sequence arrangement, BNT162b2 and mRNA-1273 mRNA synthetic molecules appear to be suitable targets for L1 retroposition in trans because they structurally and functionally mimic the architecture of native mRNAs that occur in the cytoplasm of eukaryotic cells (Table 1) [6,10]. In this regard, probably the most important sequence feature is their poly-A tail, which is known to be required for L1mediated retroposition (Figure 1, Table 1) [51]. However, the available information on the vaccine mRNA engineering logic reveals that vaccine mRNAs were not specifically constructed to avoid capture by the L1 retroposition machinery $[1,2,6,10,56]$. In fact, it seems that no study in the mRNA vaccine field considered this possibility, e.g., $[4,6,10,13,31]$. For instance, the poly-A tail of BNT162b2 mRNA contains a 10nucleotide-long linker sequence that is flanked by 30- and 70-nucleotide-long adenosine tracts [132]. Nevertheless, this poly-A tail modification, which helps in increasing translational efficiency [133,147], is unlikely to affect the retroposition propensity of the vaccine mRNA because only nucleotide changes directly neighboring the $3^{\prime}$ end of the poly-A tail are known to have a significant impact on the L1 retroposition mechanism [51,52,102]. Moreover, non-adenosine nucleotides at the $3^{\prime}$ end of the poly-A tail are generally avoided in mRNA therapeutics, as they hamper translational efficiency [148]. Similarly, because of the total number of modified nucleotides per mRNA molecule, the $\mathrm{m} 1 \Psi$ ribonucleoside modification is perhaps the most striking artificial feature of the vaccine mRNAs; however, these types of ribonucleoside modifications generally do not prevent reverse transcription [149].

\section{Parental Genes and BNT162b2}

In the comparative context, genes known to actively generate retrocopies (parental genes) in extant 279 populations (Figure 1B) are the best reference to assess general mRNA sequence trends related to retroposition. However, the collective properties of parental genes have not been extensively analyzed. Some studies report that parental genes are enriched in translation, ribosome, intracellular lumen and cell-divisionrelated functional categories [37,62,64] and that they have a weak tendency to be highly expressed [37], but a more detailed analysis is still missing. It is helpful then to explore here some basic sequence properties of mRNAs transcribed from parental genes that are known to actively generate retrocopies in extant populations $[37,40]$ and then to relate this information to the vaccine mRNA sequence that is publicly available (i.e., BNT162b2).

The current estimate of 503 parental genes in humans [37] is lower than in mice, where 1663 of them are recovered [40]. However, a study in mice that used an improved retrocopy detection pipeline and higher sequencing depths found that the number of parental genes has not reached saturation; thus, the actual number of parental genes should be expected to be higher, especially in humans [40]. Regardless of this inherent incompleteness, the available datasets showed that both mouse and human parental genes have a broad distribution of mRNA lengths (Figure 2A,B). It is also evident that the mRNAs of parental genes tend to have slightly longer sequences than the average for all protein-coding genes (Figure 2A,B). Under the caveat that I considered here only the longest splicing variant per gene, and that shorter and intronless genes might be 
The first preprint version posted on OSF preprints (July 26, 2021). The published version of this preprint is available at [https://www.mdpi.com/20734425/13/5/719] Citation: Domazet-Lošo, T. mRNA Vaccines: Why Is the Biology of Retroposition lgnored? Genes 2022, 13, 719. https://doi.org/10.3390/genes13050719

overlooked in the retrocopy/parental gene detection pipelines, this result revealed that L1-mediated 296 retroposition in trans is modulated to some extent by parental gene mRNA sequence length. In any case, the 297 sequence length of BNT162b2 mRNA falls very close to the average mRNA length of parental genes (Figure 298 $2 \mathrm{~A}, \mathrm{~B})$, indicating that the sequence length of BNT162b2 mRNA will likely not be an obstacle to retroposition. 
The first preprint version posted on OSF preprints (July 26, 2021). The published version of this preprint is available at [https://www.mdpi.com/20734425/13/5/719] Citation: Domazet-Lošo, T. mRNA Vaccines: Why Is the Biology of Retroposition lgnored? Genes 2022, 13, 719. https://doi.org/10.3390/genes13050719
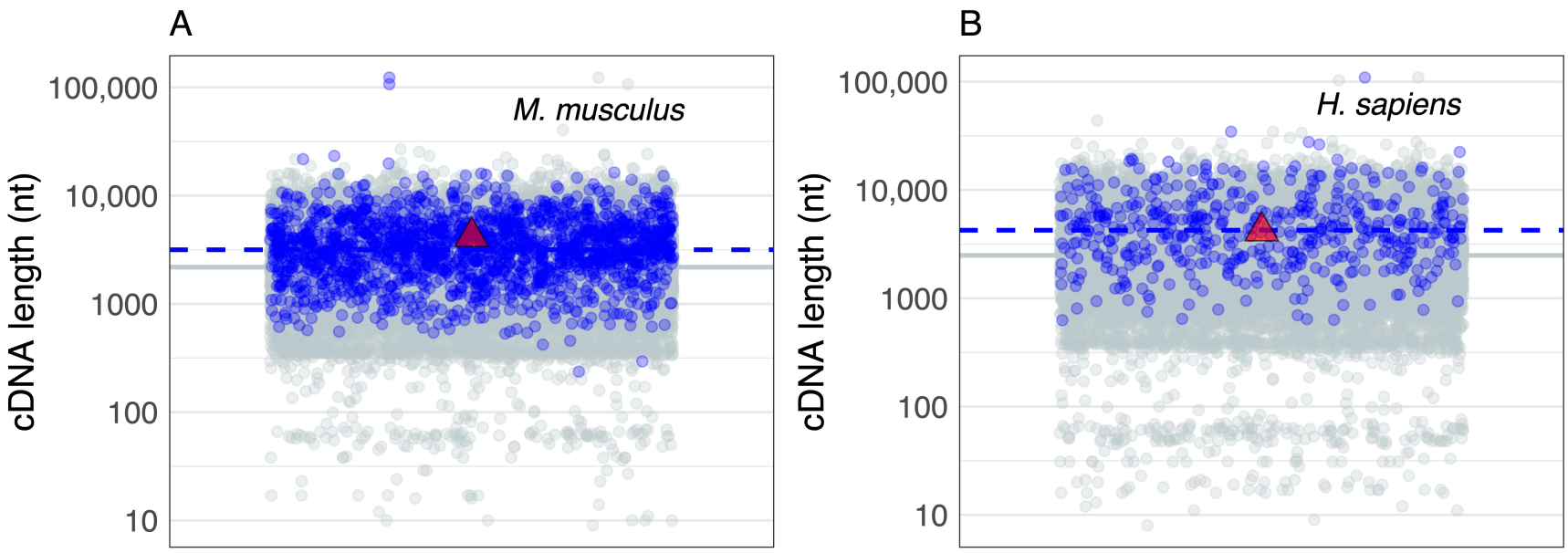

\section{C}
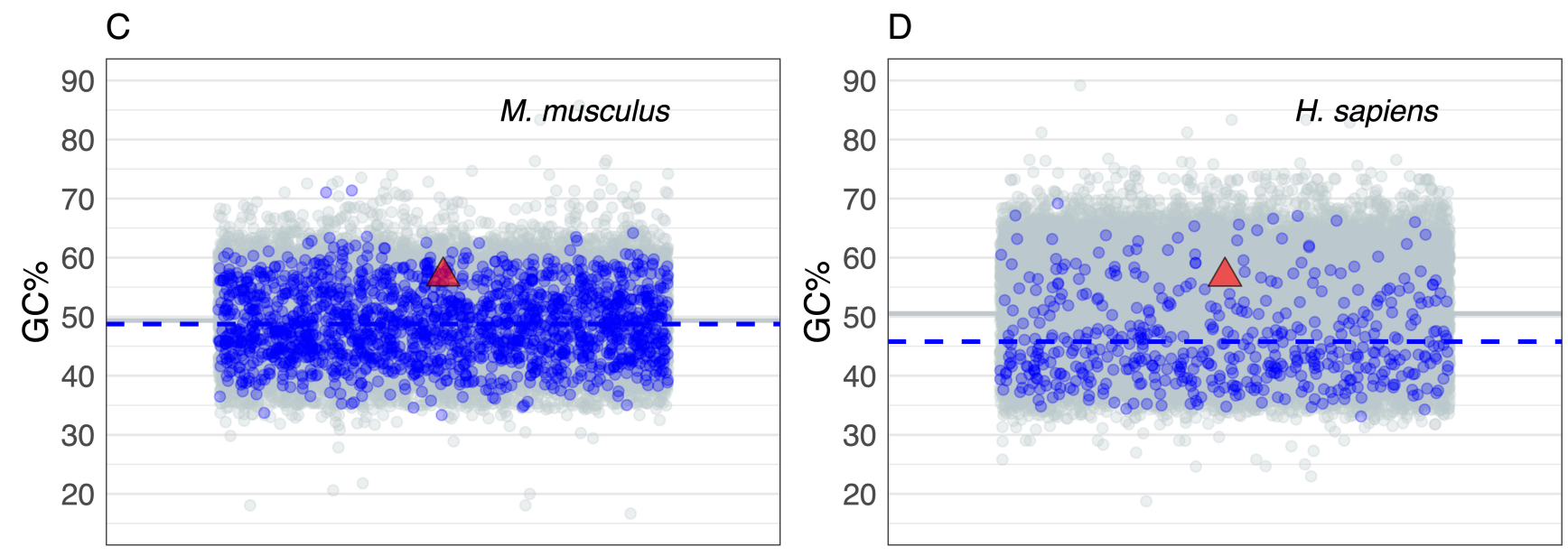

$\mathrm{E}$
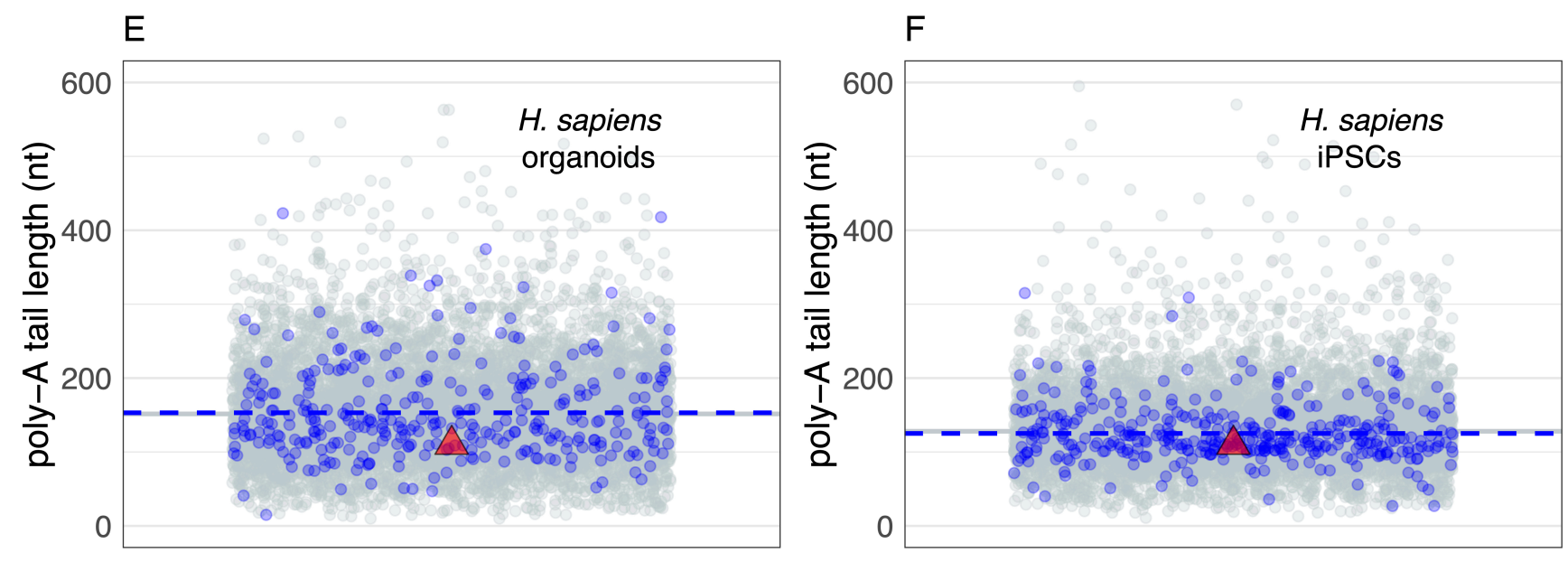

Parental $\triangle$ BNT162b2 All genes
genes

Figure 2. The basic sequence properties of BNT162b2 mRNA are within the range of parental genes that generate retrocopies. The jitter plots show parental genes (blue dots) and all genes (gray dots) randomly 
The first preprint version posted on OSF preprints (July 26, 2021). The published version of this preprint is available at [https://www.mdpi.com/20734425/13/5/719] Citation: Domazet-Lošo, T. mRNA Vaccines: Why Is the Biology of Retroposition Ignored? Genes 2022, 13, 719. https://doi.org/10.3390/genes13050719

distributed along the $\mathrm{x}$-axis. The red triangles show the BNT162b2 mRNA values. The significance of the difference between the parental genes average (blue dashed line) and the all genes average (gray solid line) was tested using a permutation test (two-tailed, $10^{6}$ permutations). The initial lists contained 503 human [37] and 1663 mouse parental gene names [40]. All mouse and 496 human parental gene names were successfully linked to the sequence data. Poly-A tail lengths were obtained for 7760 (organoids, replicate 1) and 9132 (iPSCs, replicate 1) human genes by averaging multiple estimates per gene [89]. (A) The comparison of cDNA lengths in mice ( $p=0 ; 22,770$ all genes, 1663 parental genes, Ensembl GRCm38.86). (B) The comparison of cDNA lengths in humans ( $p=0 ; 22,964$ all genes, 496 parental genes, Ensemble GRCh38.86). (C) The comparison of GC content in mice $(p=0.00021 ; 22,770$ all genes, 1663 parental genes, Ensembl GRCm38.86). (D) The comparison of GC contents in humans ( $p=0 ; 22,964$ all genes, 498 parental genes, Ensemble GRCh38.86). (E) The comparison of poly-A tail lengths in human-iPSC-derived cerebral organoids ( $p=0.69 ; 7760$ all genes, 330 parental genes, Ensemble GRCh38.84). (F) The comparison of poly-A tail lengths in human induced pluripotent stem cells (iPSCs) ( $p=0.26$; 9132 all genes, 369 parental genes, Ensemble GRCh38.84).

To improve their translation and stability, vaccine mRNAs are frequently sequence- and/or codon-optimized $[1,6,56,150]$ and this optimization could affect the GC content. Hence, I explored the GC content in mice and humans to see whether BNT162b2 mRNA is outside the range of parental genes. Similar to the mRNA length analysis, the GC content of parental genes shows a broad range of values (Figure 2C,D). In mice, the average GC content of parental genes is almost equal to the genome average (Figure 2C), whereas, in humans, parental genes tend to have slightly lower values (Figure 2D). Although the GC content of BNT162b2 mRNA is higher than the average of parental genes, it is well within their range (Figure 2C,D); thus it is unlikely that the peculiarities of the BNT162b2 GC content will prevent its retroposition.

The mRNA sequences analyzed so far correspond to bioinformatic cDNA sequences; i.e., coding sequence plus untranslated regions, excluding the poly-A tail. Commonly, poly-A tails are not considered in genomebased analyses because they are post-transcriptionally added and it was technically challenging to precisely recover their nucleotide sequence. However, poly-A tail sequencing approaches at the transcriptome scale are continuously improving and recently produced datasets provide an opportunity to gain insight into the distribution of their lengths [89]. Here, I explored poly-A tail lengths estimated using FLAM-seq in human induced pluripotent stem cells (iPSCs) and iPSCs-derived cerebral organoids [89]. I found no difference between the average poly-A tail lengths of known parental genes and all coding genes (Figure 1E,F). The distribution range of parental gene poly-A tail lengths is rather broad (Figure 1E,F), indicating that L1 machinery is mostly insensitive to the variation in poly-A tail lengths. The BNT162b2 poly-A tail with 110 nucleotides is well within the range of these values; therefore, no specific difficulties in retroposition regarding 
The first preprint version posted on OSF preprints (July 26, 2021). The published version of this preprint is available at [https://www.mdpi.com/20734425/13/5/719] Citation: Domazet-Lošo, T. mRNA Vaccines: Why Is the Biology of Retroposition Ignored? Genes 2022, 13, 719. https://doi.org/10.3390/genes13050719

This simple ad hoc comparative analysis, which covers the length, GC content and poly-A tail length of parental genes that actively produce retrocopies in extant populations (Figure 2), could be expanded by considering other datasets and sequence traits, or by using more sophisticated analytical approaches. However, its main purpose is to show that effectively any poly-A tail containing mRNA in human cells, including vaccine mRNAs, has some chance to be integrated into the genome by L1 machinery. It also reveals that is very incautious to assume without testing that mRNA-based therapeutics are integration-safe, e.g., [6,10,2325].

\section{Pharmacology Aspects}

Synthetic mRNAs have rather complex pharmacology that is dependent on their nucleotide sequence, formulation and administration route $[10,56,143]$. The likelihood of synthetic mRNA genome integration via L1 elements, besides the nucleotide sequence, depends on its distribution in tissues and organs, and eventually on its concentration and stability in the cell cytosol (Table 1). The quantity of synthetic mRNA in a single dose is the initial factor that determines the pharmacokinetics and pharmacodynamics of mRNA vaccines $[10,143]$; hence, it is helpful to consider the declared values for BNT162b2 and mRNA-1273. In a single 30 $\mu \mathrm{g}$ BNT162b2 dose $[1,140]$, there are around $1.3 \times 10^{13}$ synthetic mRNA molecules. If we ignore the loss of vaccine mRNAs on the route to the cytosol and assume their homogenous distribution among roughly $3 \times 10^{12}$ nucleated cells in the human body [153], then every nucleated cell could receive about 26 mRNA copies. This is a substantial amount if compared to the expressed human protein-coding genes that have on average 25 mRNA copies per cell [154]. These values show that the quantity of vaccine mRNA delivered in a single dose of BNT162b2 is large enough to theoretically reprogram the transcriptome of every single human cell that in principle can undergo retroposition. The undisclosed sequence of mRNA-1273 vaccine prevents a similar calculation, but under the assumption that its sequence length and nucleotide composition are comparable to BNT162b2 [2,5,56], the number of mRNA molecules per nucleated cell is possibly even higher because a single dose of mRNA-1273 vaccine contains $100 \mu \mathrm{g}$ of synthetic mRNA [2,56]. This calculation provides the theoretical upper bound of vaccine mRNA cellular uptake; however, the lower bound is much more challenging to estimate due to the complex pharmacology of synthetic mRNAs [10] and the rather limited data in the literature $[1,2,56,140]$.

After intramuscular inoculation, BNT162b2 and mRNA-1273 mRNA molecules should reach the cell cytosol where they are translated to SARS-CoV-2 spike proteins, which eventually elicit the protective immune response $[1,2,56,143,155]$. On this road from the entry site to the cell cytosol, some naked and unmodified mRNAs would be mostly degraded by the omnipresent extracellular ribonucleases $[5,6,10,156]$. The remaining mRNAs that eventually enter the cell through endocytosis predominantly end up entrapped in endosomes and degrade over time $[10,56,155,156]$. On top of this, naked mRNAs with unmodified nucleosides are detected in the endosome and cytosol by pattern recognition receptors, which, by triggering the interferon signaling and other pathways, promote RNA degradation, induce inflammation and inhibit 
The first preprint version posted on OSF preprints (July 26, 2021). The published version of this preprint is available at [https://www.mdpi.com/20734425/13/5/719] Citation: Domazet-Lošo, T. mRNA Vaccines: Why Is the Biology of Retroposition Ignored? Genes 2022, 13, 719. https://doi.org/10.3390/genes13050719

translation and replication $[5,10,56]$. Therefore, even if some external mRNAs reach the cytosol, their halflife should be largely compromised. These multiple innate immunity mechanisms against external RNAs show that eukaryotic cells are under strong selective pressure to avoid transcriptome reprogramming. By preventing the entry and activity of external mRNAs in the cytosol, these protective mechanisms also largely preclude the possible interaction of external mRNAs and endogenous L1 machinery and consequently lower the chances that some exogenous mRNAs undergo retroposition.

However, for mRNA vaccines to be effective, they must overcome these innate defense mechanisms against exogenous RNAs, reach the cytosol and have to be efficiently translated by ribosomes $[6,10]$. In the case of BNT162b2 and mRNA-1273 vaccines, this is achieved by elaborate sequence optimizations and nucleoside modifications that stabilize synthetic mRNAs and make them largely invisible to innate defense mechanisms (Table 1) $[1,2,6,10,56]$. To further protect them from the harsh extracellular environments, they are formulated in lipid nanoparticles (LNPs) that facilitate their cellular uptake and cytosol entry via endosomal escape $[1,2,10,56,143]$. It is important to note that these remarkable engineering achievements that improve vaccine mRNA cytosol delivery inadvertently increase the chances of vaccine mRNA retroposition (Table 1, Figure 1C). This shortcoming stems from the fact that, in principle, any improvement in the vaccine mRNA cytosol delivery increases the probability of interaction with the endogenous L1 machinery. Nevertheless, regardless of the increased stability and LNP formulation of vaccine mRNAs, a substantial fraction of the initial dose is degraded and will never reach the cytosol $[143,155]$. Unfortunately, accessible information in the public domain on BNT162b2 and mRNA-1273 does not reveal which percentage of the initial vaccine mRNA dose becomes bioavailable in the cytosol $[1,2,143]$. In any case, any further improvement in the cytosol delivery of vaccine mRNAs, which is a heavily pursued goal in the mRNA vaccinology field $[6,10,143,155,157,158]$, will concomitantly increase the chances of L1-mediated retroposition (Figure 1C, Table 1).

Every mRNA molecule in the cytosol will eventually decay through one of many degradation pathways $[159,160]$. In contrast to exogenous vaccine mRNAs that once degraded are not replaced $[6,10,157]$, the levels of endogenous mRNAs are controlled by the interplay between transcription and decay $[159,160]$. If all other parameters are ignored, this would mean that the probability of L1-mediated retroposition is higher for an endogenous gene with typical levels of expression than for a vaccine mRNA that is transiently present in the cell. However, several additional factors increase the chances of vaccine mRNA retroposition. The number of received doses per individual directly increases the chance of retroposition because it prolongs the time for the encounter of vaccine mRNA with L1 machinery (Table 1). Initially, BNT162b2 and mRNA-1273 were administered intramuscularly as a series of two doses, three weeks and one month apart, respectively $[1,2,56]$. However, later on, additional booster vaccinations were introduced [141,142]. It is evident that any increase in the number of required doses further increases the chances of vaccine mRNA retroposition. This could be a particularly prominent problem if the mRNA vaccines would require long-term recurrent applications, as in the case of the current seasonal vaccination program against influenza [142,161]. 
The first preprint version posted on OSF preprints (July 26, 2021). The published version of this preprint is available at [https://www.mdpi.com/20734425/13/5/719] Citation: Domazet-Lošo, T. mRNA Vaccines: Why Is the Biology of Retroposition Ignored? Genes 2022, 13, 719. https://doi.org/10.3390/genes 13050719

An additional property that influences the likelihood of vaccine mRNA genome integration is the stability of vaccine mRNA molecules. The turnover of endogenous mRNA molecules in eukaryotic cells shows great variability, with an estimated average half-life of around $7 \mathrm{~h}$ [138]. The precise measurements of the vaccine mRNA half-life in cells are not publicly available [1,2], but it is clear that the sequence and codon optimization of vaccine mRNAs increases their functional half-life with an aim to improve their translation efficiency $[6,10,27,56,138,139]$. Undoubtedly, this prolonged functional half-life increases the chances that vaccine mRNAs encounter L1 machinery and eventually retropose into the genome (Table 1). In addition, it remains unexplored how vaccine mRNAs interact with ribonucleoprotein granules that participate in the regulation of mRNA storage and decay $[28,159,162,163]$, as well as with the cytoplasm-residing L1 ribonucleoprotein particles [164].

\section{Biodistribution Profiles}

A biodistribution profile is another important parameter that determines the likelihood of vaccine mRNA genome integration because the activity of L1 elements differs between the cells, tissues and organs [99,100,114]. Interestingly, direct biodistribution studies have not been conducted for the BNT162b2 vaccine [1]. However, surrogate studies in mice and rats indicate distribution, in different quantities, from the injection site to most tissues, including liver, adrenal glands, spleen and gonads [1]. Direct distribution and pharmacokinetic studies for the mRNA-1273 vaccine were also not conducted, but studies in rats using the same LNPs and a cocktail of mRNAs encoding cytomegalovirus antigens indicate that these mRNAs, with the exception of kidney, could be detected at varying levels in all examined tissues, including the injection site muscle, proximal and distal lymph nodes, spleen, eyes, heart, lung, brain and testis [2]. Notably, the distribution of mRNA to ovaries was not tested because no female rats were included in this study, as explained in the regulatory documents [2]. Obviously, these surrogate biodistribution profiles substantially overlap with organs known to show the activity of L1 elements, such as liver [127], spleen [106], brain [60,99,117-121], adrenal glands [106], muscles [104,131,165] and gonads [96,105,106,109,112] (Table 1). If the quantity of vaccine mRNA in a single dose of BNT162b2 or mRNA-1273 is considered, these neither strictly localized nor fully systemic distribution patterns suggest that in some tissues, vaccine mRNA likely accumulates in rather high concentrations, with the potential to saturate the exogenous mRNA uptake capacity of recipient cells $[10,166]$. To more precisely evaluate the probability of L1 mediated retroposition, it is important to understand which cell types can uptake vaccine mRNA. Dendritic cells and macrophages present at the inoculation site and draining nodes are, according to the regulatory body, the two principal cell types targeted by BNT162b2 and mRNA-1273 vaccines [167]. However, the assessment report for the BNT162b2 vaccine stated that it is unknown whether cells other than professional antigen-presenting cells (APCs) may transiently express the vaccine-derived spike protein [1]. Similarly, the mRNA-1273 vaccine assessment report declared that the delivered vaccine mRNA is mainly expressed by macrophages and dendritic cells [2]. This apparently reveals that the mRNA-1273 is expressed in some other cell types as well. It is also indicative 
The first preprint version posted on OSF preprints (July 26, 2021). The published version of this preprint is available at [https://www.mdpi.com/20734425/13/5/719] Citation: Domazet-Lošo, T. mRNA Vaccines: Why Is the Biology of Retroposition Ignored? Genes 2022, 13, 719. https://doi.org/10.3390/genes 13050719

that the mechanisms of action that would drive BNT162b2 and mRNA-1273 exclusively/preferentially to dendritic cells and macrophages, if they exist, were not explained in these documents $[1,2,167]$.

Although macrophages and dendritic cells, as professional antigen-presenting cells (APCs), are specialized in sampling their environment, essentially all nucleated cells are endocytosis competent. The evidence from several studies indicates that the cellular uptake of the mRNA LNPs relies on the apolipoprotein E (ApoE) binding to LNPs and their subsequent endocytosis that is facilitated by low-density lipoprotein (LDL) receptors $[56,166,168,169]$. Since ApoE, LDL and LDL-like receptors are expressed by many cell types throughout the body $[170,171]$, it could be expected that APCs are not the only cell types that internalize mRNA LNPs [56,169]. For example, some studies indicate that myocytes, epithelial cells and fibroblasts take up vaccine mRNA and contribute to its expression [56,172-174]. These considerations suggest that cell types other than dendritic cells and macrophages most likely internalize BNT162b2 and mRNA-1273 vaccine mRNAs and that the potential encounter of L1 machinery and vaccine mRNAs may occur in diverse cell types within the broad range of tissues (Table 1).

Another level of complexity in the transport and uptake of LNP-formulated exogenous mRNA arises with the recent finding that, after endocytosis, LNPs containing mRNA are repackaged in late endosomes and secreted back into extracellular space as extracellular vesicles (EVs) (Figure 1C) [57]. These vaccine mRNA EVs (endo-EVs) protect exogenous mRNA in extracellular fluids during in vivo transport to other organs and deliver intact exogenous mRNA to the cytoplasm of the distant recipient cells [57,58,175-177]. Because of their small size, vaccine mRNA EVs are less visible than LNPs to innate immunity mechanisms and can pass through the vascular endothelium and the extracellular matrix [57,178]. Given that many cell types, including dendritic cells [179] and macrophages [180], secrete EVs, the range of cells and tissues that exogenous mRNAs could reach is substantially broadened compared to the LNPs route only (Figure 1C). A recent study showed that L1 mRNAs in cultured cells could also be packaged into EVs, delivered via EVs to recipient cells and retroposed into their genome (Figure 1A) [53]. Together, this suggests that the dynamics of EVs substantially raise the odds for the interaction between active L1 elements and vaccine mRNAs (Figure 1C, Table 1).

The possibility of vaccine mRNA genome integration in somatic and germline cells (Figure 1) is not the only adverse effect that should be considered. Theoretically, the vaccine mRNA could also be epigenetically inherited via the sperm RNA cargo [181-184]. This could happen if the testis cells of the male germinative lineage take up LNPs or EVs containing vaccine mRNAs, and if these mRNAs then end up in spermatozoa $[182,183,185]$. Alternatively, during their functional maturation in the epididymis, spermatozoa could potentially actively internalize vaccine mRNAs delivered by epididymal EVs $[184,185]$. The presence and integration of vaccine mRNAs in human spermatozoa could be relatively easily tested because the semen of vaccinated men, compared to other integration-relevant tissues, is a relatively accessible body fluid. 
The first preprint version posted on OSF preprints (July 26, 2021). The published version of this preprint is available at [https://www.mdpi.com/20734425/13/5/719] Citation: Domazet-Lošo, T. mRNA Vaccines: Why Is the Biology of Retroposition Ignored? Genes 2022, 13, 719. https://doi.org/10.3390/genes13050719

There are some further points that should be mentioned. Several papers reported that the infection of human cells by viruses, including SARS-CoV-2, increases the activity of their endogenous L1 retroelements [54,55,144-146], which is consistent with the presumed environmental modulation of L1 activity [114]. These findings suggest that, paradoxically, mRNA vaccination during active or after resolved viral infection might increase the chances of vaccine mRNA genome integration. The COVID-19 vaccine mRNAs code for the SARS-CoV-2 spike protein [56]; therefore, it is important to know whether there is any evidence that SARSCoV-2 mRNAs could integrate into the genome. Indeed, a recent study shows that upon infection, SARSCoV-2 subgenomic mRNAs can be reverse-transcribed by L1 elements and integrated into the genome of infected cells [54], although another study partly challenges these results [55]. Interestingly, fragments of mRNAs closer to the $3^{\prime}$ end of the SARS-CoV-2 genome, including the spike mRNA, are more frequently integrated into the cell DNA than the sequences closer to the 5' end [54]. This integration bias could be related to the differences in the abundance of SARS-CoV-2 subgenomic mRNAs [186], as suggested by the authors [54]. However, it could also reflect the nested architecture of subgenomic mRNAs [186] coupled with the mechanism of L1 retroposition that relies on the poly-A tail [51] and is prone to truncate transcripts with increasing distance from the $3^{\prime}$ end.

L1 retrotransposon activity is closely linked with replication $[47,86,187,188]$, and it was suggested that the retroposition of cellular mRNAs is coupled to cell divisions [37,64]. This implies that the risk of vaccine mRNA genome integration might be increased in human proliferating cell populations. The biodistribution profiles of vaccine mRNA are not available for tumors; however, increased replication activity, coupled with elevated L1 retrotransposition in tumor cells [84], make them a favorable environment for possible vaccine mRNA genome integration (Table 1). In this regard, it would be very informative to test the biodistribution profile of mRNA vaccines in murine tumor models and to look for eventual somatic retroposition events. Indeed, around six months after the preprint version of this paper was made public, an experimental study was published that reported the high-level uptake of BNT162b2 and its reverse transcription in a human liver tumor cell line [189].

At first glance, it appears that the application of mRNA vaccines could not alter the primary retroposition rates at the individual and population levels. The underlying reason is that vaccine mRNAs are not directly mutagenic and that their route to potential genome integration hinges on the endogenous cellular mechanisms, i.e., the activity of L1 elements that continuously operate on the available mRNA pool. Nevertheless, the possible change in primary retroposition rates should not be immediately dismissed because it cannot be excluded without testing that vaccination with LNP-formulated mRNAs does not modulate L1 activity. As already explained, it is well established that many exogenous factors modify L1 activity [114], including viral infections [54,55,144-146]; therefore, the impact of mRNA vaccination should also be evaluated in this regard.

On the other hand, it is apparent that eventual vaccine mRNA genome integration broadens the spectrum of conceivable sequences that could be retrocopied (Figure 1). Our cells evolved under mutational pressure that 
The first preprint version posted on OSF preprints (July 26, 2021). The published version of this preprint is available at [https://www.mdpi.com/20734425/13/5/719] Citation: Domazet-Lošo, T. mRNA Vaccines: Why Is the Biology of Retroposition Ignored? Genes 2022, 13, 719. https://doi.org/10.3390/genes 13050719

came from the activity of L1 elements that generate retrocopies of our native genes [37,40]. However, the transfection of human cells with exogenous and artificially modified mRNAs, which have the potential to be retrocopied into the genome (Figure 1C), extends the standard mutational sequence space to the realm of transgenic modifications. It is rather clear that any possibility of transgenesis in humans has ethical concerns that should be properly addressed. This raises two questions: Who is responsible for testing the likelihood of vaccine mRNA retroposition, and who will be responsible for eventual genome modifications resulting from the application of emergency-use mRNA vaccines? The answers to these questions are, without doubt, of outstanding importance for society at large.

The retroposition of a vaccine mRNA molecule is, in principle, a random event that can occur in any transfected cell that shows the activity of L1 elements (Figure 1C). The clonal expansion of a new retrocopy largely depends on its phenotypic effects and the pre-existing proliferative capacity of the mutated cell. On one extreme, a vaccine mRNA retrocopy that directly inactivates an essential gene $[113,190]$ would result in cell death that would preclude any further spread of that retrocopy. However, a retrocopy that is moderately deleterious or neutral $[76,191]$ and has emerged in a cell with high proliferative potential has good odds to be propagated to a large number of descendant cells. In adults, the proliferative capacity of many cells in the soma is considerably limited [191,192] and it further drops with aging [193]. This implies that the vaccine mRNA retrocopy mosaicism in the adult soma should be largely restricted to smaller cell clusters or individual cells. Nevertheless, a retroposition event in a progenitor cell, an adult stem cell [194] or a premalignant cell [193] would lead to clonal expansion of the retrocopy in much larger chunks of somatic tissue.

In contrast to the relatively confined effects of somatic retroposition, a possible heritable vaccine mRNA retroposition event would have a more far-reaching impact by rendering fully transgenic individuals. The hypothetical vaccine mRNA retrocopy with heritable potential could occur in germinative cells or in the pluripotent cells of early embryos [113]. As already discussed above, the documents of regulatory agencies state that the surrogate biodistribution studies reported the distribution of LNP-formulated mRNA to gonads [1,2], which are known to display the activity of L1 elements [96,99,105,106,109-112]. On the other hand, vaccine mRNA stored in the sperm RNA cargo could hypothetically reach the pluripotent cells of early embryos, which are the hotspots of L1 activity [93-95,97,107,108] and undergo retroposition there. This, in turn, could result in somatic mosaicism, where a substantial part of cells in an individual could become transgenic, and if the gonads are also affected, the retrocopy could become heritable [97,113].

The phenotype of a vaccine mRNA retrocopy will depend, among other factors, on the number and identity of cells that become transgenic, the insertion locus, completeness of the inserted sequence, direction of the insertion, peculiarities of the recipient genome and the expression potential of the retrocopy. Although native mRNAs lack transcription-driving elements, it is well established that most of their retrocopies show evidence of transcription [38,40,41]; hence, it could be expected that a hypothetical vaccine mRNA retrocopy would also have good chances to be expressed. Many expressed retrocopies of native genes tend to have a strong negative impact on fitness and are, therefore, relatively quickly purged from the population [40]. It was 
The first preprint version posted on OSF preprints (July 26, 2021). The published version of this preprint is available at [https://www.mdpi.com/20734425/13/5/719] Citation: Domazet-Lošo, T. mRNA Vaccines: Why Is the Biology of Retroposition Ignored? Genes 2022, 13, 719. https://doi.org/10.3390/genes13050719

suggested that these deleterious effects of expressed retrocopies are often related to the interference with their parental genes [40]. Since a hypothetical vaccine mRNA retrocopy does not have a parental gene in the host genome (Figure 1C), effects related to the expression interference between the retrocopy and its parental gene are not possible. However, an expressed retrocopy of vaccine mRNA could interact in unpredictable ways with the host immune system, later viral infections, vaccine mRNAs received in subsequent administration rounds and native mRNAs. For instance, the antisense-transcribed UTR regions of a vaccine mRNA retrocopy could potentially silence complementary transcripts of human globin genes [43,195-197].

\section{Conclusions}

Current engineering strategies [150] and declared future directions [150,198] for the improvement of mRNA vaccines do not consider the possibility of vaccine mRNA genome integration via L1 retroelements native to human cells. This is at odds with the knowledge base on the biology of L1-mediated retroposition and its role in the genetics, development and evolution of humans. Why this risk is overlooked is even more obscure given that mRNA retroposition is a biomedically recognized phenomenon outside vaccinology $[44,49,62,65,66,68,69,77,79,80,83]$. To alleviate these discrepancies between the fields, it would be critical to design and perform experimental studies on animal models that aim to detect the existence of vaccine mRNA retrocopies and estimate their retroposition frequencies. In this endeavor, the single-cell sequencing of various tissues will likely play a pivotal role [191]. As the retroposition propensity via L1 retroelements is sequencedependent, it would be advisable to independently test every mRNA therapeutic candidate. This information could then guide further vaccine mRNA refinements in the direction of avoiding active L1 cellular environments [199] or by improving their resilience to the L1 machinery capture [102].

Every technology is a double-edged sword and mRNA therapeutics are not an exception. In this complex COVID-19 crisis, it is essential that all pros and cons of control measures, procedures, treatments, prophylaxis and vaccine technologies are continually openly discussed and cautiously evaluated from many angles [200]. An encouraging example in this direction is the recently published papers that, in a balanced way, discuss the largely ignored negative aspects of COVID-19 pandemic control measures and practices on the overall human microbiome [201], neonatal microbiome [202] and immunity [203]. I hope that the possible interplay between mRNA vaccines and L1 elements presented here will also provoke debate and attract the attention of researchers in a broad range of disciplines, e.g., [204].

Whether the current vaccine mRNAs could integrate into the genome, and by which frequency, has to be ultimately demonstrated using experiments. However, it remains puzzling why and how the mRNA vaccinology field neglected the retroposition biology of L1 retroelements and its theoretical links to possible vaccine mRNA retroposition, especially when one considers the volume, visibility and significance of the L1 $[44,45,60,83-85,117,131]$ and retroposition research [36-41,45,46,49,60,66,68,77,80]. The mRNA vaccinology field started its development more than 30 years ago [11,31] and L1 retroelements in humans have been studied for more than 40 years $[205,206]$ but obviously without any crosstalk between the two 
The first preprint version posted on OSF preprints (July 26, 2021). The published version of this preprint is available at [https://www.mdpi.com/20734425/13/5/719] Citation: Domazet-Lošo, T. mRNA Vaccines: Why Is the Biology of Retroposition Ignored? Genes 2022, 13, 719. https://doi.org/10.3390/genes13050719

fields. This awkward silo effect points to the fact that, on some occasions, the structural drawbacks of contemporary science, despite its amassment, globalization and unprecedented dissemination, are deeper than we are willing to admit. Unfortunately, all of this creates an impression that L1-driven retroposition is a kind of taboo topic in mRNA vaccinology.

I conclude that the broadly reiterated statement that mRNA-based therapeutics could not impact genomes is an unfounded assumption of unclear origin. This implies that the current mRNA vaccine evaluations, which lack studies that specifically address genome integration, are insufficient to declare their genome integration safety. We should not forget that mRNAs are information-bearing molecules that can, in principle, encode any information [207]. From this perspective, an mRNA vaccination could be viewed as a sort of "molecular tattooing". It is, therefore, important that the exact nucleotide sequences of mRNA vaccines are disclosed and easily publicly accessible, including product information documents [208,209], to allow for unambiguous and independent tracking of possible vaccine mRNA integration in the somatic and germinative genomes of already vaccinated people and their progeny.

Funding: This work was supported in part by the Croatian Science Foundation under the project IP-2016-065924, the Adris Foundation and the European Regional Development Fund (KK.01.1.1.01.0009 DATACROSS).

Data Availability Statement: Publicly available datasets were analyzed in this study. The mouse and human sequence data is available in the Ensembl repository: [http://ftp.ensembl.org/pub/]. The lists of parental genes are available in the supplementary material of the respective references [37,40]. The human poly-A tail data is available in the NCBI GEO database: [https://www.ncbi.nlm.nih.gov/geo/query/acc.cgi?acc=GSE126465].

Acknowledgments: I thank S. Koska for assistance with bioinformatics; S. Koska and N. Čorak for figure preparation; M. Futo for help with manuscript formatting; and S. Koska, N. Črak and M. Futo for critically reading the manuscript.

Conflicts of Interest: The author declares no conflict of interest.

\section{References}

1. European Medicines Agency. Comirnaty Assessment Report. 2020, EMA/707383/2020. Available online: https://www.ema.europa.eu/en/documents/assessment-report/comirnaty-epar-publicassessment-report_en.pdf (accessed on 30 December 2020).

2. European Medicines Agency. COVID-19 Vaccine Moderna Assessment Report. 2021, EMA/15689/2021. Available online: https://www.ema.europa.eu/en/documents/assessment- 
The first preprint version posted on OSF preprints (July 26, 2021). The published version of this preprint is available at [https://www.mdpi.com/20734425/13/5/719] Citation: Domazet-Lošo, T. mRNA Vaccines: Why Is the Biology of Retroposition Ignored? Genes 2022, 13, 719. https://doi.org/10.3390/genes13050719

report/covid-19-vaccine-moderna-epar-public-assessment-report_en.pdf (accessed on 27 January 2021).

3. Funk, C.D.; Laferrière, C.; Ardakani, A. A Snapshot of the Global Race for Vaccines Targeting SARSCoV-2 and the COVID-19 Pandemic. Front. Pharmacol. 2020, $11,937$. https://doi.org/10.3389/fphar.2020.00937.

4. Knezevic, I.; Liu, M.A.; Peden, K.; Zhou, T.; Kang, H.-N. Development of MRNA Vaccines: Scientific and Regulatory Issues. Vaccines 2021, 9, 81. https://doi.org/10.3390/vaccines9020081.

5. Park, J.W.; Lagniton, P.N.P.; Liu, Y.; Xu, R.-H. MRNA Vaccines for COVID-19: What, Why and How. Int. J. Biol. Sci. 2021, 17, 1446-1460. https://doi.org/10.7150/ijbs.59233.

6. Pardi, N.; Hogan, M.J.; Porter, F.W.; Weissman, D. MRNA Vaccines - a New Era in Vaccinology. Nat. Rev. Drug Discov. 2018, 17, 261-279. https://doi.org/10.1038/nrd.2017.243.

7. Jackson, N.A.C.; Kester, K.E.; Casimiro, D.; Gurunathan, S.; DeRosa, F. The Promise of MRNA Vaccines: A Biotech and Industrial Perspective. npj Vaccines 2020, 5, 11. https://doi.org/10.1038/s41541-020-0159-8.

8. Cannon, G.; Weissman, D. RNA Based Vaccines. DNA Cell Biol. 2002, 21, 953-961. https://doi.org/10.1089/104454902762053882.

9. Geall, A.J.; Mandl, C.W.; Ulmer, J.B. RNA: The New Revolution in Nucleic Acid Vaccines. Semin. Immunol. 2013, 25, 152-159. https://doi.org/10.1016/j.smim.2013.05.001.

10. Sahin, U.; Karikó, K.; Türeci, Ö. MRNA-Based Therapeutics-Developing a New Class of Drugs. Nat. Rev. Drug Discov. 2014, 13, 759-780. https://doi.org/10.1038/nrd4278.

11. Verbeke, R.; Lentacker, I.; De Smedt, S.C.; Dewitte, H. Three Decades of Messenger RNA Vaccine Development. Nano Today 2019, 28, 100766. https://doi.org/10.1016/j.nantod.2019.100766.

12. Zhang, C.; Maruggi, G.; Shan, H.; Li, J. Advances in MRNA Vaccines for Infectious Diseases. Front. Immunol. 2019, 10, 594. https://doi.org/10.3389/fimmu.2019.00594.

13. Tombácz, I.; Weissman, D.; Pardi, N. Vaccination with Messenger RNA: A Promising Alternative to DNA Vaccination. In DNA Vaccines; Sousa, Â., Ed.; Methods in Molecular Biology; Springer US: New York, NY, USA, 2021; Volume 2197, pp. 13-31. ISBN 978-1-07-160871-5.

14. Kreiter, S.; Diken, M.; Selmi, A.; Türeci, Ö.; Sahin, U. Tumor Vaccination Using Messenger RNA: Prospects of a Future Therapy. Curr. Opin. Immunol. 2011, 23, 399-406. https://doi.org/10.1016/j.coi.2011.03.007.

15. Weissman, D. MRNA Transcript Therapy. Expert Rev. Vaccines 2015, 14, 265-281. https://doi.org/10.1586/14760584.2015.973859.

16. Maruggi, G.; Zhang, C.; Li, J.; Ulmer, J.B.; Yu, D. MRNA as a Transformative Technology for Vaccine Development to Control Infectious Diseases. Mol. Ther. 2019, 27, 757-772. https://doi.org/10.1016/j.ymthe.2019.01.020. 
The first preprint version posted on OSF preprints (July 26, 2021). The published version of this preprint is available at [https://www.mdpi.com/20734425/13/5/719] Citation: Domazet-Lošo, T. mRNA Vaccines: Why Is the Biology of Retroposition lgnored? Genes 2022, 13, 719. https://doi.org/10.3390/genes13050719

17. Dammes, N.; Peer, D. Paving the Road for RNA Therapeutics. Trends Pharmacol. Sci. 2020, 41, 755775. https://doi.org/10.1016/j.tips.2020.08.004.

18. Fuller, D.H.; Berglund, P. Amplifying RNA Vaccine Development. N. Engl. J. Med. 2020, 382, 24692471. https://doi.org/10.1056/NEJMcibr2009737.

19. Gerer, K.F.; Hoyer, S.; Dörrie, J.; Schaft, N. Electroporation of MRNA as Universal Technology Platform to Transfect a Variety of Primary Cells with Antigens and Functional Proteins. In RNA Vaccines; Kramps, T., Elbers, K., Eds.; Methods in Molecular Biology; Springer New York: New York, NY, USA, 2017; Volume 1499, pp. 165-178. ISBN 978-1-4939-6479-6.

20. Pardi, N.; Weissman, D. Nucleoside Modified MRNA Vaccines for Infectious Diseases. In RNA Vaccines; Kramps, T., Elbers, K., Eds.; Methods in Molecular Biology; Springer New York: New York, NY, USA, 2017; Vol. 1499, pp. 109-121 ISBN 978-1-4939-6479-6.

21. Hinz, T.; Kallen, K.; Britten, C.M.; Flamion, B.; Granzer, U.; Hoos, A.; Huber, C.; Khleif, S.; Kreiter, S.; Rammensee, H.-G.; et al. The European Regulatory Environment of RNA-Based Vaccines. In RNA Vaccines; Kramps, T., Elbers, K., Eds.; Methods in Molecular Biology; Springer New York: New York, NY, USA, 2017; Volume 1499, pp. 203-222. ISBN 978-1-4939-6479-6.

22. Naik, R.; Peden, K. Regulatory Considerations on the Development of MRNA Vaccines. In Current Topics in Microbiology and Immunology; Springer: Berlin/Heidelberg, Germany, 2020.

23. World Health Organization. Evaluation of the Quality, Safety and Efficacy of RNA-Based Prophylactic Vaccines for Infectious Diseases: Regulatory Considerations. (Draft). 2020, Available online: https://www.who.int/docs/default-source/biologicals/ecbs/reg-considerations-on-rnavaccines_1st-draft_pc_tz_22122020.pdf (accessed on 11 January 2021).

24. World Health Organization. Background Document on the mRNA Vaccine BNT162b2 (PfizerBioNTech) against COVID-19. 2021, Available online: https://www.who.int/publications/i/item/background-document-on-mrna-vaccine-bnt162b2-(pfizerbiontech)-against-covid-19 (accessed on 12 February 2021).

25. World Health Organization. Background Document on the mRNA-1273 Vaccine (Moderna) against COVID-19. 2021, Available online: https://www.who.int/publications/i/item/background-documenton-the-mrna-1273-vaccine-(moderna)-against-covid-19 (accessed on 12 February 2021).

26. Youn, H.; Chung, J.-K. Modified MRNA as an Alternative to Plasmid DNA (PDNA) for Transcript Replacement and Vaccination Therapy. Expert Opin. Biol. Ther. 2015, 15, 1337-1348. https://doi.org/10.1517/14712598.2015.1057563.

27. Orlandini von Niessen, A.G.; Poleganov, M.A.; Rechner, C.; Plaschke, A.; Kranz, L.M.; Fesser, S.; Diken, M.; Löwer, M.; Vallazza, B.; Beissert, T.; et al. Improving MRNA-Based Therapeutic Gene Delivery by Expression-Augmenting 3' UTRs Identified by Cellular Library Screening. Mol. Ther. 2019, 27, 824-836. https://doi.org/10.1016/j.ymthe.2018.12.011. 
The first preprint version posted on OSF preprints (July 26, 2021). The published version of this preprint is available at [https://www.mdpi.com/20734425/13/5/719] Citation: Domazet-Lošo, T. mRNA Vaccines: Why Is the Biology of Retroposition Ignored? Genes 2022, 13, 719. https://doi.org/10.3390/genes13050719

28. Kuhn, A.N.; Beissert, T.; Simon, P.; Vallazza, B.; Buck, J.; Davies, B.; Tureci, O.; Sahin, U. MRNA as a Versatile Tool for Exogenous Protein Expression. CGT 2012, 12, 347-361. https://doi.org/10.2174/156652312802762536.

29. Phua, K.K.L.; Leong, K.W.; Nair, S.K. Transfection Efficiency and Transgene Expression Kinetics of MRNA Delivered in Naked and Nanoparticle Format. J. Control. Release 2013, 166, 227-233. https://doi.org/10.1016/j.jconrel.2012.12.029.

30. Yamamoto, A.; Kormann, M.; Rosenecker, J.; Rudolph, C. Current Prospects for MRNA Gene Delivery. Eur. J. Pharm. Biopharm. 2009, 71, 484-489. https://doi.org/10.1016/j.ejpb.2008.09.016.

31. Liu A Comparison of Plasmid DNA and MRNA as Vaccine Technologies. Vaccines 2019, 7, 37. https://doi.org/10.3390/vaccines7020037.

32. Cimolai, N. Do RNA Vaccines Obviate the Need for Genotoxicity Studies? Mutagenesis 2020, 35, 509-510. https://doi.org/10.1093/mutage/geaa028.

33. Meurens, F. Flu RNA Vaccine: A Game Changer? Vaccines 2020, 8, 760. https://doi.org/10.3390/vaccines8040760.

34. Doerfler, W. Adenoviral Vector DNA- and SARS-CoV-2 MRNA-Based Covid-19 Vaccines: Possible Integration into the Human Genome-Are Adenoviral Genes Expressed in Vector-Based Vaccines? Virus Res. 2021, 302, 198466. https://doi.org/10.1016/j.virusres.2021.198466.

35. Wadhwa, A.; Aljabbari, A.; Lokras, A.; Foged, C.; Thakur, A. Opportunities and Challenges in the

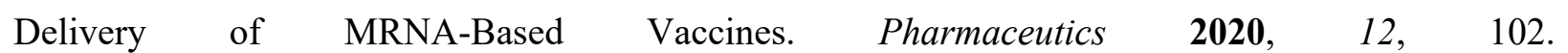
https://doi.org/10.3390/pharmaceutics12020102.

36. Kaessmann, H.; Vinckenbosch, N.; Long, M. RNA-Based Gene Duplication: Mechanistic and Evolutionary Insights. Nat. Rev. Genet. 2009, 10, 19-31. https://doi.org/10.1038/nrg2487.

37. Zhang, Y.; Li, S.; Abyzov, A.; Gerstein, M.B. Landscape and Variation of Novel Retroduplications in 26 Human Populations. PLoS Comput. Biol. 2017, 13, e1005567. https://doi.org/10.1371/journal.pcbi.1005567.

38. Casola, C.; Betrán, E. The Genomic Impact of Gene Retrocopies: What Have We Learned from Comparative Genomics, Population Genomics, and Transcriptomic Analyses? Genome Biol. Evol. 2017, 9, 1351-1373. https://doi.org/10.1093/gbe/evx081.

39. Cheetham, S.W.; Faulkner, G.J.; Dinger, M.E. Overcoming Challenges and Dogmas to Understand the Functions of Pseudogenes. Nat. Rev. Genet. 2020, 21, 191-201. https://doi.org/10.1038/s41576019-0196-1.

40. Zhang, W.; Xie, C.; Ullrich, K.; Zhang, Y.E.; Tautz, D. The Mutational Load in Natural Populations Is Significantly Affected by High Primary Rates of Retroposition. Proc. Natl. Acad. Sci. USA 2021, 118, e2013043118. https://doi.org/10.1073/pnas.2013043118.
715

716

717

718

719

720

721 
The first preprint version posted on OSF preprints (July 26, 2021). The published version of this preprint is available at [https://www.mdpi.com/20734425/13/5/719] Citation: Domazet-Lošo, T. mRNA Vaccines: Why Is the Biology of Retroposition Ignored? Genes 2022, 13, 719. https://doi.org/10.3390/genes13050719

41. Carelli, F.N.; Hayakawa, T.; Go, Y.; Imai, H.; Warnefors, M.; Kaessmann, H. The Life History of Retrocopies Illuminates the Evolution of New Mammalian Genes. Genome Res. 2016, 26, 301-314. https://doi.org/10.1101/gr.198473.115.

42. Horie, M.; Honda, T.; Suzuki, Y.; Kobayashi, Y.; Daito, T.; Oshida, T.; Ikuta, K.; Jern, P.; Gojobori, T.; Coffin, J.M.; et al. Endogenous Non-Retroviral RNA Virus Elements in Mammalian Genomes. Nature 2010, 463, 84-87. https://doi.org/10.1038/nature08695.

43. Parrish, N.F.; Fujino, K.; Shiromoto, Y.; Iwasaki, Y.W.; Ha, H.; Xing, J.; Makino, A.; KuramochiMiyagawa, S.; Nakano, T.; Siomi, H.; et al. PiRNAs Derived from Ancient Viral Processed Pseudogenes as Transgenerational Sequence-Specific Immune Memory in Mammals. RNA 2015, 21, 1691-1703. https://doi.org/10.1261/rna.052092.115.

44. Beck, C.R.; Garcia-Perez, J.L.; Badge, R.M.; Moran, J.V. LINE-1 Elements in Structural Variation and Disease. Annu. Rev. Genom. Hum. Genet. 2011, 12, 187-215. https://doi.org/10.1146/annurevgenom-082509-141802.

45. Kazazian, H.H.; Moran, J.V. Mobile DNA in Health and Disease. N. Engl. J. Med. 2017, 377, 361370. https://doi.org/10.1056/NEJMra1510092.

46. Esnault, C.; Maestre, J.; Heidmann, T. Human LINE Retrotransposons Generate Processed Pseudogenes. Nat. Genet. 2000, 24, 363-367. https://doi.org/10.1038/74184.

47. Mita, P.; Wudzinska, A.; Sun, X.; Andrade, J.; Nayak, S.; Kahler, D.J.; Badri, S.; LaCava, J.; Ueberheide, B.; Yun, C.Y.; et al. LINE-1 Protein Localization and Functional Dynamics during the Cell Cycle. eLife 2018, 7, e30058. https://doi.org/10.7554/eLife.30058.

48. Naufer, M.N.; Furano, A.V.; Williams, M.C. Protein-Nucleic Acid Interactions of LINE-1 ORF1p. Semin. Cell Dev. Biol. 2019, 86, 140-149. https://doi.org/10.1016/j.semcdb.2018.03.019.

49. Hancks, D.C.; Kazazian, H.H. Roles for Retrotransposon Insertions in Human Disease. Mob. DNA 2016, 7, 9. https://doi.org/10.1186/s13100-016-0065-9.

50. Boeke, J.D. LINEs and Alus - the PolyA Connection. Nat. Genet. 1997, 16, 6-7. 753 https://doi.org/10.1038/ng0597-6.

51. Doucet, A.J.; Wilusz, J.E.; Miyoshi, T.; Liu, Y.; Moran, J.V. A 3' Poly(A) Tract Is Required for LINE1 Retrotransposition. Mol. Cell 2015, 60, 728-741. https://doi.org/10.1016/j.molcel.2015.10.012.

52. Monot, C.; Kuciak, M.; Viollet, S.; Mir, A.A.; Gabus, C.; Darlix, J.-L.; Cristofari, G. The Specificity and Flexibility of L1 Reverse Transcription Priming at Imperfect T-Tracts. PLoS Genet. 2013, 9, e1003499. https://doi.org/10.1371/journal.pgen.1003499.

53. Kawamura, Y.; Sanchez Calle, A.; Yamamoto, Y.; Sato, T.-A.; Ochiya, T. Extracellular Vesicles Mediate the Horizontal Transfer of an Active LINE-1 Retrotransposon. J. Extracell. Vesicles 2019, 8, 1643214. https://doi.org/10.1080/20013078.2019.1643214.

54. Zhang, L.; Richards, A.; Barrasa, M.I.; Hughes, S.H.; Young, R.A.; Jaenisch, R. Reverse-Transcribed SARS-CoV-2 RNA Can Integrate into the Genome of Cultured Human Cells and Can Be Expressed 
The first preprint version posted on OSF preprints (July 26, 2021). The published version of this preprint is available at [https://www.mdpi.com/20734425/13/5/719] Citation: Domazet-Lošo, T. mRNA Vaccines: Why Is the Biology of Retroposition Ignored? Genes 2022, 13, 719. https://doi.org/10.3390/genes13050719

in Patient-Derived Tissues. Proc. Natl. Acad. Sci. USA 2021, 118, e2105968118. 765 https://doi.org/10.1073/pnas.2105968118.

55. Smits, N.; Rasmussen, J.; Bodea, G.O.; Amarilla, A.A.; Gerdes, P.; Sanchez-Luque, F.J.; Ajjikuttira, P.; Modhiran, N.; Liang, B.; Faivre, J.; et al. No Evidence of Human Genome Integration of SARSCoV-2 Found by Long-Read DNA Sequencing. Cell. Rep. 2021, 36, 109530. https://doi.org/10.1016/j.celrep.2021.109530.

56. Verbeke, R.; Lentacker, I.; De Smedt, S.C.; Dewitte, H. The Dawn of MRNA Vaccines: The COVID19 Case. J. Control. Release 2021, 333, 511-520. https://doi.org/10.1016/j.jconrel.2021.03.043.

57. Maugeri, M.; Nawaz, M.; Papadimitriou, A.; Angerfors, A.; Camponeschi, A.; Na, M.; Hölttä, M.; Skantze, P.; Johansson, S.; Sundqvist, M.; et al. Linkage between Endosomal Escape of LNP-MRNA and Loading into EVs for Transport to Other Cells. Nat. Commun. 2019, 10, 4333. https://doi.org/10.1038/s41467-019-12275-6.

58. Valadi, H.; Ekström, K.; Bossios, A.; Sjöstrand, M.; Lee, J.J.; Lötvall, J.O. Exosome-Mediated Transfer of MRNAs and MicroRNAs Is a Novel Mechanism of Genetic Exchange between Cells. Nat. Cell Biol. 2007, 9, 654-659. https://doi.org/10.1038/ncb1596.

59. Pei, B.; Sisu, C.; Frankish, A.; Howald, C.; Habegger, L.; Mu, X.; Harte, R.; Balasubramanian, S.; Tanzer, A.; Diekhans, M.; et al. The GENCODE Pseudogene Resource. Genome Biol. 2012, 13, R51. https://doi.org/10.1186/gb-2012-13-9-r51.

60. Richardson, S.R.; Salvador-Palomeque, C.; Faulkner, G.J. Diversity through Duplication: Wholegenome Sequencing Reveals Novel Gene Retrocopies in the Human Population. BioEssays 2014, 36, 475-481. https://doi.org/10.1002/bies.201300181.

61. Navarro, F.C.P.; Galante, P.A.F. A Genome-Wide Landscape of Retrocopies in Primate Genomes. Genome Biol. Evol. 2015, 7, 2265-2275. https://doi.org/10.1093/gbe/evv142.

62. Ewing, A.D.; Ballinger, T.J.; Earl, D.; Broad Institute Genome Sequencing and Analysis Program and Platform; Harris, C.C.; Ding, L.; Wilson, R.K.; Haussler, D. Retrotransposition of Gene Transcripts Leads to Structural Variation in Mammalian Genomes. Genome Biol. 2013, 14, R22. https://doi.org/10.1186/gb-2013-14-3-r22.

63. Schrider, D.R.; Navarro, F.C.P.; Galante, P.A.F.; Parmigiani, R.B.; Camargo, A.A.; Hahn, M.W.; de Souza, S.J. Gene Copy-Number Polymorphism Caused by Retrotransposition in Humans. PLoS Genet. 2013, 9, e1003242. https://doi.org/10.1371/journal.pgen.1003242.

64. Abyzov, A.; Iskow, R.; Gokcumen, O.; Radke, D.W.; Balasubramanian, S.; Pei, B.; Habegger, L.; The 1000 Genomes Project Consortium; Lee, C.; Gerstein, M. Analysis of Variable Retroduplications in Human Populations Suggests Coupling of Retrotransposition to Cell Division. Genome Res. 2013, 23, 2042-2052. https://doi.org/10.1101/gr.154625.113.

65. Chatron, N.; Cassinari, K.; Quenez, O.; Baert-Desurmont, S.; Bardel, C.; Buisine, M.; Calpena, E.; Capri, Y.; Corominas Galbany, J.; Diguet, F.; et al. Identification of Mobile Retrocopies during 
The first preprint version posted on OSF preprints (July 26, 2021). The published version of this preprint is available at [https://www.mdpi.com/20734425/13/5/719] Citation: Domazet-Lošo, T. mRNA Vaccines: Why Is the Biology of Retroposition Ignored? Genes 2022, 13, 719. https://doi.org/10.3390/genes13050719

Genetic Testing: Consequences for Routine Diagnosis. Human Mutat. 2019, 40, 1993-2000. 801 https://doi.org/10.1002/humu.23845.

66. Gardner, E.J.; Prigmore, E.; Gallone, G.; Danecek, P.; Samocha, K.E.; Handsaker, J.; Gerety, S.S.; Ironfield, H.; Short, P.J.; Sifrim, A.; et al. Contribution of Retrotransposition to Developmental Disorders. Nat. Commun. 2019, 10, 4630. https://doi.org/10.1038/s41467-019-12520-y.

67. Parker, H.G.; VonHoldt, B.M.; Quignon, P.; Margulies, E.H.; Shao, S.; Mosher, D.S.; Spady, T.C.; Elkahloun, A.; Cargill, M.; Jones, P.G.; et al. An Expressed Fgf4 Retrogene Is Associated with BreedDefining Chondrodysplasia in Domestic Dogs. Science 2009, 325, 995-998. https://doi.org/10.1126/science.1173275.

68. De Boer, M.; van Leeuwen, K.; Geissler, J.; Weemaes, C.M.; van den Berg, T.K.; Kuijpers, T.W.; Warris, A.; Roos, D. Primary Immunodeficiency Caused by an Exonized Retroposed Gene Copy Inserted in the CYBB Gene. Human Mutat. 2014, 35, 486-496. https://doi.org/10.1002/humu.22519.

69. Kazazian, H.H. Processed Pseudogene Insertions in Somatic Cells. Mob. DNA 2014, 5, 20. https://doi.org/10.1186/1759-8753-5-20.

70. Djebali, S.; Davis, C.A.; Merkel, A.; Dobin, A.; Lassmann, T.; Mortazavi, A.; Tanzer, A.; Lagarde, J.; Lin, W.; Schlesinger, F.; et al. Landscape of Transcription in Human Cells. Nature 2012, 489, 101108. https://doi.org/10.1038/nature11233.

71. Hangauer, M.J.; Vaughn, I.W.; McManus, M.T. Pervasive Transcription of the Human Genome Produces Thousands of Previously Unidentified Long Intergenic Noncoding RNAs. PLoS Genet. 2013, 9, e1003569. https://doi.org/10.1371/journal.pgen.1003569.

72. Neme, R.; Tautz, D. Fast Turnover of Genome Transcription across Evolutionary Time Exposes Entire Non-Coding DNA to de Novo Gene Emergence. elife 2016, 5, e09977. https://doi.org/10.7554/eLife.09977.

73. Tautz, D.; Domazet-Lošo, T. The Evolutionary Origin of Orphan Genes. Nat. Rev. Genet. 2011, 12, 692-702. https://doi.org/10.1038/nrg3053.

74. Rohozinski, J.; Lamb, D.J.; Bishop, C.E. UTP14c Is a Recently Acquired Retrogene Associated with Spermatogenesis and Fertility in Man1. Biol. Reprod. 2006, 74, 644-651. https://doi.org/10.1095/biolreprod.105.046698.

75. Ciomborowska, J.; Rosikiewicz, W.; Szklarczyk, D.; Makalowski, W.; Makalowska, I. "Orphan" Retrogenes in the Human Genome. Mol. Biol. Evol. 2013, 30, 384-396. https://doi.org/10.1093/molbev/mss235.

76. Domazet-Loso, T.; Tautz, D. An Ancient Evolutionary Origin of Genes Associated with Human Genetic Diseases. Mol. Biol. Evol. 2008, 25, 2699-2707. https://doi.org/10.1093/molbev/msn214.

77. ICGC Breast Cancer Group; Cooke, S.L.; Shlien, A.; Marshall, J.; Pipinikas, C.P.; Martincorena, I.; 
The first preprint version posted on OSF preprints (July 26, 2021). The published version of this preprint is available at [https://www.mdpi.com/20734425/13/5/719] Citation: Domazet-Lošo, T. mRNA Vaccines: Why Is the Biology of Retroposition Ignored? Genes 2022, 13, 719. https://doi.org/10.3390/genes13050719

78. Scott, E.; Devine, S. The Role of Somatic L1 Retrotransposition in Human Cancers. Viruses 2017, $9, \quad 837$ 131. https://doi.org/10.3390/v9060131.

79. Bim, L.V.; Navarro, F.C.P.; Valente, F.O.F.; Lima-Junior, J.V.; Delcelo, R.; Dias-da-Silva, M.R.; 839 Maciel, R.M.B.; Galante, P.A.F.; Cerutti, J.M. Retroposed Copies of RET Gene: A Somatically 840 Acquired Event in Medullary Thyroid Carcinoma. BMC Med. Genom. 2019, 12, 104.841 https://doi.org/10.1186/s12920-019-0552-1.

80. PCAWG Structural Variation Working Group; PCAWG Consortium; Rodriguez-Martin, B.; Alvarez, E.G.; Baez-Ortega, A.; Zamora, J.; Supek, F.; Demeulemeester, J.; Santamarina, M.; Ju, Y.S.; et al. Pan-Cancer Analysis of Whole Genomes Identifies Driver Rearrangements Promoted by LINE-1 Retrotransposition. Nat. Genet. 2020, 52, 306-319. https://doi.org/10.1038/s41588-019-0562-0.

81. Tan, S.; Cardoso-Moreira, M.; Shi, W.; Zhang, D.; Huang, J.; Mao, Y.; Jia, H.; Zhang, Y.; Chen, C.; Shao, Y.; et al. LTR-Mediated Retroposition as a Mechanism of RNA-Based Duplication in Metazoans. Genome Res. 2016, 26, 1663-1675. https://doi.org/10.1101/gr.204925.116.

82. International Human Genome Sequencing Consortium Initial Sequencing and Analysis of the Human Genome. Nature 2001, 409, 860-921. https://doi.org/10.1038/35057062.

83. Payer, L.M.; Burns, K.H. Transposable Elements in Human Genetic Disease. Nat. Rev. Genet. 2019, 20, 760-772. https://doi.org/10.1038/s41576-019-0165-8.

84. Burns, K.H. Transposable Elements in Cancer. Nat. Rev. Cancer 2017, 17, 415-424. 854 https://doi.org/10.1038/nrc.2017.35.

85. Burns, K.H. Our Conflict with Transposable Elements and Its Implications for Human Disease. Annu. Rev. Pathol. Mech. Dis. 2020, 15, 51-70. https://doi.org/10.1146/annurev-pathmechdis-012419032633.

86. Denli, A.M.; Narvaiza, I.; Kerman, B.E.; Pena, M.; Benner, C.; Marchetto, M.C.N.; Diedrich, J.K.; Aslanian, A.; Ma, J.; Moresco, J.J.; et al. Primate-Specific ORF0 Contributes to RetrotransposonMediated Diversity. Cell 2015, 163, 583-593. https://doi.org/10.1016/j.cell.2015.09.025.

87. Taylor, M.S.; Altukhov, I.; Molloy, K.R.; Mita, P.; Jiang, H.; Adney, E.M.; Wudzinska, A.; Badri, S.; Ischenko, D.; Eng, G.; et al. Dissection of Affinity Captured LINE-1 Macromolecular Complexes. eLife 2018, 7, e30094. https://doi.org/10.7554/eLife.30094.

88. Moldovan, J.B.; Wang, Y.; Shuman, S.; Mills, R.E.; Moran, J.V. RNA Ligation Precedes the Retrotransposition of U6/LINE-1 Chimeric RNA. Proc. Natl. Acad. Sci. USA 2019, 116, $20612-$ 20622. https://doi.org/10.1073/pnas.1805404116.

89. Legnini, I.; Alles, J.; Karaiskos, N.; Ayoub, S.; Rajewsky, N. FLAM-Seq: Full-Length MRNA Sequencing Reveals Principles of Poly(A) Tail Length Control. Nat. Methods 2019, 16, 879-886. https://doi.org/10.1038/s41592-019-0503-y. 
The first preprint version posted on OSF preprints (July 26, 2021). The published version of this preprint is available at [https://www.mdpi.com/20734425/13/5/719] Citation: Domazet-Lošo, T. mRNA Vaccines: Why Is the Biology of Retroposition Ignored? Genes 2022, 13, 719. https://doi.org/10.3390/genes13050719

90. Wei, W.; Gilbert, N.; Ooi, S.L.; Lawler, J.F.; Ostertag, E.M.; Kazazian, H.H.; Boeke, J.D.; Moran, J.V. Human L1 Retrotransposition: Cis Preference versus Trans. Complementation. Mol. Cell. Biol. 2001, 21, 1429-1439. https://doi.org/10.1128/MCB.21.4.1429-1439.2001.

91. Kulpa, D.A.; Moran, J.V. Cis-Preferential LINE-1 Reverse Transcriptase Activity in 874 Ribonucleoprotein Particles. Nat. Struct. Mol. Biol. 2006, 13, 655-660. https://doi.org/10.1038/nsmb1107.

92. Ahl, V.; Keller, H.; Schmidt, S.; Weichenrieder, O. Retrotransposition and Crystal Structure of an Alu RNP in the Ribosome-Stalling Conformation. Mol. Cell 2015, 60, 715-727. https://doi.org/10.1016/j.molcel.2015.10.003.

93. Percharde, M.; Sultana, T.; Ramalho-Santos, M. What Doesn't Kill You Makes You Stronger: Transposons as Dual Players in Chromatin Regulation and Genomic Variation. BioEssays 2020, 42, 1900232. https://doi.org/10.1002/bies.201900232.

94. Beraldi, R.; Pittoggi, C.; Sciamanna, I.; Mattei, E.; Spadafora, C. Expression of LINE-1 Retroposons Is Essential for Murine Preimplantation Development. Mol. Reprod. Dev. 2006, 73, 279-287. https://doi.org/10.1002/mrd.20423.

95. Jachowicz, J.W.; Bing, X.; Pontabry, J.; Bošković, A.; Rando, O.J.; Torres-Padilla, M.-E. LINE-1 Activation after Fertilization Regulates Global Chromatin Accessibility in the Early Mouse Embryo. Nat. Genet. 2017, 49, 1502-1510. https://doi.org/10.1038/ng.3945.

96. Newkirk, S.J.; Lee, S.; Grandi, F.C.; Gaysinskaya, V.; Rosser, J.M.; Vanden Berg, N.; Hogarth, C.A.; Marchetto, M.C.N.; Muotri, A.R.; Griswold, M.D.; et al. Intact PiRNA Pathway Prevents L1 Mobilization in Male Meiosis. Proc. Natl. Acad. Sci. USA 2017, 114, E5635-E5644. https://doi.org/10.1073/pnas.1701069114.

97. Richardson, S.R.; Faulkner, G.J. Heritable L1 Retrotransposition Events During Development: Understanding Their Origins: Examination of Heritable, Endogenous L1 Retrotransposition in Mice Opens up Exciting New Questions and Research Directions. BioEssays 2018, 40, 1700189. https://doi.org/10.1002/bies.201700189.

98. Schwertz, H.; Rowley, J.W.; Schumann, G.G.; Thorack, U.; Campbell, R.A.; Manne, B.K.; Zimmerman, G.A.; Weyrich, A.S.; Rondina, M.T. Endogenous LINE-1 (Long Interspersed Nuclear Element-1) Reverse Transcriptase Activity in Platelets Controls Translational Events Through RNADNA Hybrids. ATVB 2018, 38, 801-815. https://doi.org/10.1161/ATVBAHA.117.310552.

99. Levin, H.L.; Moran, J.V. Dynamic Interactions between Transposable Elements and Their Hosts. Nat. Rev. Genet. 2011, 12, 615-627. https://doi.org/10.1038/nrg3030.

100. Goodier, J.L. Restricting Retrotransposons: A Review. Mob. DNA 2016, 7, 16.903 https://doi.org/10.1186/s13100-016-0070-z. 
The first preprint version posted on OSF preprints (July 26, 2021). The published version of this preprint is available at [https://www.mdpi.com/20734425/13/5/719] Citation: Domazet-Lošo, T. mRNA Vaccines: Why Is the Biology of Retroposition Ignored? Genes 2022, 13, 719. https://doi.org/10.3390/genes13050719

101. Pizarro, J.G.; Cristofari, G. Post-Transcriptional Control of LINE-1 Retrotransposition by

Cellular Host Factors in Somatic Cells. Front. Cell Dev. Biol. 2016, 4. https://doi.org/10.3389/fcell.2016.00014.

102. Warkocki, Z.; Krawczyk, P.S.; Adamska, D.; Bijata, K.; Garcia-Perez, J.L.; Dziembowski, A. Uridylation by TUT4/7 Restricts Retrotransposition of Human LINE-1s. Cell 2018, 174, 15371548.e29. https://doi.org/10.1016/j.cell.2018.07.022.

103. Sanchez-Luque, F.J.; Kempen, M.-J.H.C.; Gerdes, P.; Vargas-Landin, D.B.; Richardson, S.R.;

Troskie, R.-L.; Jesuadian, J.S.; Cheetham, S.W.; Carreira, P.E.; Salvador-Palomeque, C.; et al. LINE1 Evasion of Epigenetic Repression in Humans. Mol. Cell 2019, 75, 590-604.e12. https://doi.org/10.1016/j.molcel.2019.05.024.

104. De Cecco, M.; Criscione, S.W.; Peterson, A.L.; Neretti, N.; Sedivy, J.M.; Kreiling, J.A. Transposable Elements Become Active and Mobile in the Genomes of Aging Mammalian Somatic Tissues. Aging 2013, 5, 867-883. https://doi.org/10.18632/aging.100621.

105. Ostertag, E.M.; DeBerardinis, R.J.; Goodier, J.L.; Zhang, Y.; Yang, N.; Gerton, G.L.;

Kazazian, H.H. A Mouse Model of Human L1 Retrotransposition. Nat. Genet. 2002, 32, 655-660. https://doi.org/10.1038/ng1022.

106. Belancio, V.P.; Roy-Engel, A.M.; Pochampally, R.R.; Deininger, P. Somatic Expression of

LINE-1 Elements in Human Tissues. Nucleic Acids Res. 2010, 38, 3909-3922. https://doi.org/10.1093/nar/gkq132.

107. Kano, H.; Godoy, I.; Courtney, C.; Vetter, M.R.; Gerton, G.L.; Ostertag, E.M.; Kazazian, H.H.

L1 Retrotransposition Occurs Mainly in Embryogenesis and Creates Somatic Mosaicism. Genes Dev.

2009, 23, 1303-1312. https://doi.org/10.1101/gad.1803909.

108. Kohlrausch, F.B.; Berteli, T.S.; Wang, F.; Navarro, P.A.; Keefe, D.L. Control of LINE-1

Expression Maintains Genome Integrity in Germline and Early Embryo Development. Reprod. Sci.

2021. https://doi.org/10.1007/s43032-021-00461-1.

109. Ergün, S.; Buschmann, C.; Heukeshoven, J.; Dammann, K.; Schnieders, F.; Lauke, H.; Chalajour, F.; Kilic, N.; Strätling, W.H.; Schumann, G.G. Cell Type-Specific Expression of LINE-1 Open Reading Frames 1 and 2 in Fetal and Adult Human Tissues. J. Biol. Chem. 2004, 279, 2775327763. https://doi.org/10.1074/jbc.M312985200.

110. Lazaros, L.; Kitsou, C.; Kostoulas, C.; Bellou, S.; Hatzi, E.; Ladias, P.; Stefos, T.; Markoula, S.; Galani, V.; Vartholomatos, G.; et al. Retrotransposon Expression and Incorporation of Cloned Human and Mouse Retroelements in Human Spermatozoa. Fertil. Steril. 2017, 107, 821-830. https://doi.org/10.1016/j.fertnstert.2016.12.027.

111. Giordano, R.; Magnano, A.R.; Zaccagnini, G.; Pittoggi, C.; Moscufo, N.; Lorenzini, R.; Spadafora, C. Reverse Transcriptase Activity in Mature Spermatozoa of Mouse. J. Cell Biol. 2000, 148, 1107-1114. https://doi.org/10.1083/jcb.148.6.1107.

906 
The first preprint version posted on OSF preprints (July 26, 2021). The published version of this preprint is available at [https://www.mdpi.com/20734425/13/5/719] Citation: Domazet-Lošo, T. mRNA Vaccines: Why Is the Biology of Retroposition Ignored? Genes 2022, 13, 719. https://doi.org/10.3390/genes13050719

112. Georgiou, I.; Noutsopoulos, D.; Dimitriadou, E.; Markopoulos, G.; Apergi, A.; Lazaros, L.;

Vaxevanoglou, T.; Pantos, K.; Syrrou, M.; Tzavaras, T. Retrotransposon RNA Expression and

Evidence for Retrotransposition Events in Human Oocytes. Human Mol. Genet. 2009, 18, 1221-1228.

https://doi.org/10.1093/hmg/ddp022.

113. Richardson, S.R.; Gerdes, P.; Gerhardt, D.J.; Sanchez-Luque, F.J.; Bodea, G.-O.; Muñoz-

Lopez, M.; Jesuadian, J.S.; Kempen, M.-J.H.C.; Carreira, P.E.; Jeddeloh, J.A.; et al. Heritable L1

Retrotransposition in the Mouse Primordial Germline and Early Embryo. Genome Res. 2017, 27, 1395-1405. https://doi.org/10.1101/gr.219022.116.

114. Del Re, B.; Giorgi, G. Long INterspersed Element-1 Mobility as a Sensor of Environmental Stresses. Environ. Mol. Mutagen. 2020, 61, 465-493. https://doi.org/10.1002/em.22366.

115. Rangwala, S.H.; Zhang, L.; Kazazian, H.H. Many LINE1 Elements Contribute to the Transcriptome of Human Somatic Cells. Genome Biol. 2009, 10, R100. https://doi.org/10.1186/gb2009-10-9-r100.

116. Banaz-Yaşar, F.; Steffen, G.; Hauschild, J.; Bongartz, B.M.; Schumann, G.G.; Ergün, S. LINE-

1 Retrotransposition Events Affect Endothelial Proliferation and Migration. Histochem. Cell Biol.

2010, 134, 581-589. https://doi.org/10.1007/s00418-010-0758-y.

117. Thomas, C.A.; Paquola, A.C.M.; Muotri, A.R. LINE-1 Retrotransposition in the Nervous System. Annu. Rev. Cell Dev. Biol. 2012, 28, 555-573. https://doi.org/10.1146/annurev-cellbio101011-155822.

118. Upton, K.R.; Gerhardt, D.J.; Jesuadian, J.S.; Richardson, S.R.; Sánchez-Luque, F.J.; Bodea, G.O.; Ewing, A.D.; Salvador-Palomeque, C.; van der Knaap, M.S.; Brennan, P.M.; et al. Ubiquitous L1 Mosaicism in Hippocampal Neurons. Cell 2015, 161, 228-239. https://doi.org/10.1016/j.cell.2015.03.026.

119. Erwin, J.A.; Paquola, A.C.M.; Singer, T.; Gallina, I.; Novotny, M.; Quayle, C.; Bedrosian, T.A.; Alves, F.I.A.; Butcher, C.R.; Herdy, J.R.; et al. L1-Associated Genomic Regions Are Deleted in

Somatic Cells of the Healthy Human Brain. Nat. Neurosci. 2016, 19, 1583-1591. https://doi.org/10.1038/nn.4388.

120. Faulkner, G.J.; Garcia-Perez, J.L. L1 Mosaicism in Mammals: Extent, Effects, and Evolution.

Trends Genet. 2017, 33, 802-816. https://doi.org/10.1016/j.tig.2017.07.004.

121. Terry, D.M.; Devine, S.E. Aberrantly High Levels of Somatic LINE-1 Expression and Retrotransposition in Human Neurological Disorders. Front. Genet. 2020, 10, 1244. https://doi.org/10.3389/fgene.2019.01244.

122. Bodea, G.O.; McKelvey, E.G.Z.; Faulkner, G.J. Retrotransposon-Induced Mosaicism in the Neural Genome. Open Biol. 2018, 8, 180074. https://doi.org/10.1098/rsob.180074. 
The first preprint version posted on OSF preprints (July 26, 2021). The published version of this preprint is available at [https://www.mdpi.com/20734425/13/5/719] Citation: Domazet-Lošo, T. mRNA Vaccines: Why Is the Biology of Retroposition lgnored? Genes 2022, 13, 719. https://doi.org/10.3390/genes13050719

123. Muotri, A.R.; Chu, V.T.; Marchetto, M.C.N.; Deng, W.; Moran, J.V.; Gage, F.H. Somatic Mosaicism in Neuronal Precursor Cells Mediated by L1 Retrotransposition. Nature 2005, 435, 903910. https://doi.org/10.1038/nature03663.

124. Coufal, N.G.; Garcia-Perez, J.L.; Peng, G.E.; Yeo, G.W.; Mu, Y.; Lovci, M.T.; Morell, M.; O'Shea, K.S.; Moran, J.V.; Gage, F.H. L1 Retrotransposition in Human Neural Progenitor Cells. Nature 2009, 460, 1127-1131. https://doi.org/10.1038/nature08248.

125. Baillie, J.K.; Barnett, M.W.; Upton, K.R.; Gerhardt, D.J.; Richmond, T.A.; De Sapio, F.; Brennan, P.M.; Rizzu, P.; Smith, S.; Fell, M.; et al. Somatic Retrotransposition Alters the Genetic Landscape of the Human Brain. Nature 2011, 479, 534-537. https://doi.org/10.1038/nature10531.

126. Macia, A.; Widmann, T.J.; Heras, S.R.; Ayllon, V.; Sanchez, L.; Benkaddour-Boumzaouad, M.; Muñoz-Lopez, M.; Rubio, A.; Amador-Cubero, S.; Blanco-Jimenez, E.; et al. Engineered LINE-1 Retrotransposition in Nondividing Human Neurons. Genome Res. 2017, 27, 335-348. https://doi.org/10.1101/gr.206805.116.

127. Shukla, R.; Upton, K.R.; Muñoz-Lopez, M.; Gerhardt, D.J.; Fisher, M.E.; Nguyen, T.; Brennan, P.M.; Baillie, J.K.; Collino, A.; Ghisletti, S.; et al. Endogenous Retrotransposition Activates Oncogenic Pathways in Hepatocellular Carcinoma. Cell 2013, 153, 101-111. https://doi.org/10.1016/j.cell.2013.02.032.

128. Ewing, A.D.; Gacita, A.; Wood, L.D.; Ma, F.; Xing, D.; Kim, M.-S.; Manda, S.S.; Abril, G.; Pereira, G.; Makohon-Moore, A.; et al. Widespread Somatic L1 Retrotransposition Occurs Early during Gastrointestinal Cancer Evolution. Genome Res. 2015, 25, 1536-1545. https://doi.org/10.1101/gr.196238.115.

129. Doucet-O’Hare, T.T.; Rodić, N.; Sharma, R.; Darbari, I.; Abril, G.; Choi, J.A.; Young Ahn, J.; Cheng, Y.; Anders, R.A.; Burns, K.H.; et al. LINE-1 Expression and Retrotransposition in Barrett's Esophagus and Esophageal Carcinoma. Proc. Natl. Acad. Sci. USA 2015, 112, E4894-E4900. https://doi.org/10.1073/pnas.1502474112.

130. Doucet-O’Hare, T.T.; Sharma, R.; Rodić, N.; Anders, R.A.; Burns, K.H.; Kazazian, H.H. Somatically Acquired LINE-1 Insertions in Normal Esophagus Undergo Clonal Expansion in Esophageal Squamous Cell Carcinoma: HUMAN MUTATION. Hum. Mutat. 2016, 37, 942-954. https://doi.org/10.1002/humu.23027.

131. De Cecco, M.; Ito, T.; Petrashen, A.P.; Elias, A.E.; Skvir, N.J.; Criscione, S.W.; Caligiana, A.; Brocculi, G.; Adney, E.M.; Boeke, J.D.; et al. L1 Drives IFN in Senescent Cells and Promotes AgeAssociated Inflammation. Nature 2019, 566, 73-78. https://doi.org/10.1038/s41586-018-0784-9.

132. World Health Organization. Messenger RNA Encoding the Full-Length SARS-CoV-2 Spike Glycoprotein. 2020, Entry 11889. Available online: https://web.archive.org/web/20210105162941/https://mednetcommunities.net/inn/db/media/docs/11889.doc (accessed on 30 April 2021) 
The first preprint version posted on OSF preprints (July 26, 2021). The published version of this preprint is available at [https://www.mdpi.com/20734425/13/5/719] Citation: Domazet-Lošo, T. mRNA Vaccines: Why Is the Biology of Retroposition Ignored? Genes 2022, 13, 719. https://doi.org/10.3390/genes13050719

133. Vogel, A.B.; Kanevsky, I.; Che, Y.; Swanson, K.A.; Muik, A.; Vormehr, M.; Kranz, L.M.;

Walzer, K.C.; Hein, S.; Güler, A.; et al. BNT162b Vaccines Protect Rhesus Macaques from SARSCoV-2. Nature 2021, 592, 283-289. https://doi.org/10.1038/s41586-021-03275-y.

134. Andries, O.; Mc Cafferty, S.; De Smedt, S.C.; Weiss, R.; Sanders, N.N.; Kitada, T. N1Methylpseudouridine-Incorporated MRNA Outperforms Pseudouridine-Incorporated MRNA by Providing Enhanced Protein Expression and Reduced Immunogenicity in Mammalian Cell Lines and Mice. J. Control. Release 2015, 217, 337-344. https://doi.org/10.1016/j.jconrel.2015.08.051.

135. Svitkin, Y.V.; Cheng, Y.M.; Chakraborty, T.; Presnyak, V.; John, M.; Sonenberg, N. N1Methyl-Pseudouridine in MRNA Enhances Translation through EIF2 $\alpha$-Dependent and Independent Mechanisms by Increasing Ribosome Density. Nucleic Acids Res. 2017, 45, 6023-6036. https://doi.org/10.1093/nar/gkx135.

136. Parr, C.J.C.; Wada, S.; Kotake, K.; Kameda, S.; Matsuura, S.; Sakashita, S.; Park, S.; Sugiyama, H.; Kuang, Y.; Saito, H. N 1-Methylpseudouridine Substitution Enhances the Performance of Synthetic MRNA Switches in Cells. Nucleic Acids Res. 2020, 48, e35. https://doi.org/10.1093/nar/gkaa070.

137. Corbett, K.S.; Edwards, D.K.; Leist, S.R.; Abiona, O.M.; Boyoglu-Barnum, S.; Gillespie, R.A.; Himansu, S.; Schäfer, A.; Ziwawo, C.T.; DiPiazza, A.T.; et al. SARS-CoV-2 MRNA Vaccine Design Enabled by Prototype Pathogen Preparedness. Nature 2020, 586, 567-571. https://doi.org/10.1038/s41586-020-2622-0.

138. Shi, K.; Liu, T.; Fu, H.; Li, W.; Zheng, X. Genome-Wide Analysis of LncRNA Stability in Human. PLoS Comput. Biol. 2021, 17, e1008918. https://doi.org/10.1371/journal.pcbi.1008918.

139. Mauger, D.M.; Cabral, B.J.; Presnyak, V.; Su, S.V.; Reid, D.W.; Goodman, B.; Link, K.; Khatwani, N.; Reynders, J.; Moore, M.J.; et al. MRNA Structure Regulates Protein Expression through Changes in Functional Half-Life. Proc. Natl. Acad. Sci. USA 2019, 116, 24075-24083. https://doi.org/10.1073/pnas.1908052116.

140. Polack, F.P.; Thomas, S.J.; Kitchin, N.; Absalon, J.; Gurtman, A.; Lockhart, S.; Perez, J.L.; Pérez Marc, G.; Moreira, E.D.; Zerbini, C.; et al. Safety and Efficacy of the BNT162b2 MRNA Covid19 Vaccine. N. Engl. J. Med. 2020, 383, 2603-2615. https://doi.org/10.1056/NEJMoa2034577.

141. Andrews, N.; Stowe, J.; Kirsebom, F.; Toffa, S.; Sachdeva, R.; Gower, C.; Ramsay, M.; Lopez Bernal, J. Effectiveness of COVID-19 Booster Vaccines against COVID-19-Related Symptoms, Hospitalization and Death in England. Nat. Med. 2022. https://doi.org/10.1038/s41591-022-01699-1.

142. Watson, C. Three, Four or More: What's the Magic Number for Booster Shots? Nature 2022, 602, 17-18. https://doi.org/10.1038/d41586-022-00200-9.

143. Buschmann, M.D.; Carrasco, M.J.; Alishetty, S.; Paige, M.; Alameh, M.G.; Weissman, D. Nanomaterial Delivery Systems for MRNA Vaccines. Vaccines 2021, 9, 65. https://doi.org/10.3390/vaccines9010065. 
The first preprint version posted on OSF preprints (July 26, 2021). The published version of this preprint is available at [https://www.mdpi.com/20734425/13/5/719] Citation: Domazet-Lošo, T. mRNA Vaccines: Why Is the Biology of Retroposition lgnored? Genes 2022, 13, 719. https://doi.org/10.3390/genes13050719

144. Jones, R.B.; Song, H.; Xu, Y.; Garrison, K.E.; Buzdin, A.A.; Anwar, N.; Hunter, D.V.; Mujib, S.; Mihajlovic, V.; Martin, E.; et al. LINE-1 Retrotransposable Element DNA Accumulates in HIV-1Infected Cells. J. Virol. 2013, 87, 13307-13320. https://doi.org/10.1128/JVI.02257-13.

145. Macchietto, M.G.; Langlois, R.A.; Shen, S.S. Virus-Induced Transposable Element Expression up-Regulation in Human and Mouse Host Cells. Life Sci. Alliance 2020, 3, e201900536. https://doi.org/10.26508/lsa.201900536.

146. Yin, Y.; Liu, X.; He, X.; Zhou, L. Exogenous Coronavirus Interacts with Endogenous Retrotransposon in Human Cells. Front. Cell. Infect. Microbiol. 2021, 11, 609160. https://doi.org/10.3389/fcimb.2021.609160.

147. Trepotec, Z.; Geiger, J.; Plank, C.; Aneja, M.K.; Rudolph, C. Segmented Poly(A) Tails Significantly Reduce Recombination of Plasmid DNA without Affecting MRNA Translation Efficiency or Half-Life. RNA 2019, 25, 507-518. https://doi.org/10.1261/rna.069286.118.

148. Holtkamp, S.; Kreiter, S.; Selmi, A.; Simon, P.; Koslowski, M.; Huber, C.; Türeci, Ö.; Sahin, U. Modification of Antigen-Encoding RNA Increases Stability, Translational Efficacy, and T-Cell Stimulatory Capacity of Dendritic Cells. Blood 2006, 108, 4009-4017. https://doi.org/10.1182/blood2006-04-015024.

149. Potapov, V.; Fu, X.; Dai, N.; Corrêa, I.R.; Tanner, N.A.; Ong, J.L. Base Modifications Affecting RNA Polymerase and Reverse Transcriptase Fidelity. Nucleic Acids Res. 2018, 46, $5753-$ 5763. https://doi.org/10.1093/nar/gky341.

150. Linares-Fernández, S.; Lacroix, C.; Exposito, J.-Y.; Verrier, B. Tailoring MRNA Vaccine to Balance Innate/Adaptive Immune Response. Trends Mol. Med. 2020, 26, 311-323. https://doi.org/10.1016/j.molmed.2019.10.002.

151. Zhang, N.-N.; Li, X.-F.; Deng, Y.-Q.; Zhao, H.; Huang, Y.-J.; Yang, G.; Huang, W.-J.; Gao, P.; Zhou, C.; Zhang, R.-R.; et al. A Thermostable MRNA Vaccine against COVID-19. Cell 2020, 182, 1271-1283.e16. https://doi.org/10.1016/j.cell.2020.07.024.

152. Rauch, S.; Roth, N.; Schwendt, K.; Fotin-Mleczek, M.; Mueller, S.O.; Petsch, B. MRNA Based SARS-CoV-2 Vaccine Candidate CVnCoV Induces High Levels of Virus Neutralizing Antibodies and Mediates Protection in Rodents. npj Vaccines 2020, 6, 57.

153. Sender, R.; Fuchs, S.; Milo, R. Revised Estimates for the Number of Human and Bacteria Cells in the Body. PLoS Biol. 2016, 14, e1002533. https://doi.org/10.1371/journal.pbio.1002533.

154. Marinov, G.K.; Williams, B.A.; McCue, K.; Schroth, G.P.; Gertz, J.; Myers, R.M.; Wold, B.J. From Single-Cell to Cell-Pool Transcriptomes: Stochasticity in Gene Expression and RNA Splicing. Genome Res. 2014, 24, 496-510. https://doi.org/10.1101/gr.161034.113.

155. Kim, J.; Eygeris, Y.; Gupta, M.; Sahay, G. Self-Assembled MRNA Vaccines. Adv. Drug Deliv. Rev. 2021, 170, 83-112. https://doi.org/10.1016/j.addr.2020.12.014. 
The first preprint version posted on OSF preprints (July 26, 2021). The published version of this preprint is available at [https://www.mdpi.com/20734425/13/5/719] Citation: Domazet-Lošo, T. mRNA Vaccines: Why Is the Biology of Retroposition lgnored? Genes 2022, 13, 719. https://doi.org/10.3390/genes 13050719

156. Wu, Z.; Li, T. Nanoparticle-Mediated Cytoplasmic Delivery of Messenger RNA Vaccines:

Challenges and Future Perspectives. Pharm. Res. 2021, 38, 473-478. https://doi.org/10.1007/s11095021-03015-x.

157. Hajj, K.A.; Whitehead, K.A. Tools for Translation: Non-Viral Materials for Therapeutic MRNA Delivery. Nat. Rev. Mater. 2017, 2, 17056. https://doi.org/10.1038/natrevmats.2017.56.

158. Smith, S.A.; Selby, L.I.; Johnston, A.P.R.; Such, G.K. The Endosomal Escape of

Nanoparticles: Toward More Efficient Cellular Delivery. Bioconjugate Chem. 2019, 30, 263-272. https://doi.org/10.1021/acs.bioconjchem.8b00732.

159. Garneau, N.L.; Wilusz, J.; Wilusz, C.J. The Highways and Byways of MRNA Decay. Nat. Rev. Mol. Cell Biol. 2007, 8, 113-126. https://doi.org/10.1038/nrm2104.

160. Houseley, J.; Tollervey, D. The Many Pathways of RNA Degradation. Cell 2009, 136, 763776. https://doi.org/10.1016/j.cell.2009.01.019.

161. Wei, C.-J.; Crank, M.C.; Shiver, J.; Graham, B.S.; Mascola, J.R.; Nabel, G.J. Next-Generation Influenza Vaccines: Opportunities and Challenges. Nat. Rev. Drug Discov. 2020, 19, 239-252. https://doi.org/10.1038/s41573-019-0056-x.

162. Hubstenberger, A.; Courel, M.; Bénard, M.; Souquere, S.; Ernoult-Lange, M.; Chouaib, R.; Yi, Z.; Morlot, J.-B.; Munier, A.; Fradet, M.; et al. P-Body Purification Reveals the Condensation of Repressed MRNA Regulons. Mol. Cell 2017, 68, 144-157.e5. https://doi.org/10.1016/j.molcel.2017.09.003.

163. Corbet, G.A.; Parker, R. RNP Granule Formation: Lessons from P-Bodies and Stress Granules.

Cold Spring Harb. Symp. Quant. Biol. 2019, 84, 203-215. https://doi.org/10.1101/sqb.2019.84.040329.

164. Mandal, P.K.; Ewing, A.D.; Hancks, D.C.; Kazazian, H.H. Enrichment of Processed Pseudogene Transcripts in L1-Ribonucleoprotein Particles. Hum. Mol. Genet. 2013, 22, 3730-3748. https://doi.org/10.1093/hmg/ddt225.

165. Roberson, P.A.; Romero, M.A.; Osburn, S.C.; Mumford, P.W.; Vann, C.G.; Fox, C.D.; McCullough, D.J.; Brown, M.D.; Roberts, M.D. Skeletal Muscle LINE-1 ORF1 MRNA Is Higher in Older Humans but Decreases with Endurance Exercise and Is Negatively Associated with Higher Physical Activity. J. Appl. Physiol. 2019, 127, 895-904. https://doi.org/10.1152/japplphysiol.00352.2019. https://doi.org/10.1016/j.jconrel.2015.08.007. 
The first preprint version posted on OSF preprints (July 26, 2021). The published version of this preprint is available at [https://www.mdpi.com/20734425/13/5/719] Citation: Domazet-Lošo, T. mRNA Vaccines: Why Is the Biology of Retroposition lgnored? Genes 2022, 13, 719. https://doi.org/10.3390/genes13050719

167. European Medicines Agency. Reply to Open Letter Concerning COVID-19 Vaccines. 2021,

EMA/140520/2021. Available online: https://www.ema.europa.eu/en/documents/other/reply-openletter-concerning-vaccines-covid-19_en.pdf (accessed on 29 May 2021).

168. Akinc, A.; Querbes, W.; De, S.; Qin, J.; Frank-Kamenetsky, M.; Jayaprakash, K.N.; Jayaraman, M.; Rajeev, K.G.; Cantley, W.L.; Dorkin, J.R.; et al. Targeted Delivery of RNAi Therapeutics With Endogenous and Exogenous Ligand-Based Mechanisms. Mol. Ther. 2010, 18, 1357-1364. https://doi.org/10.1038/mt.2010.85.

169. Cagigi, A.; Loré, K. Immune Responses Induced by MRNA Vaccination in Mice, Monkeys and Humans. Vaccines 2021, 9, 61. https://doi.org/10.3390/vaccines9010061.

170. Hussain, M.M.; Strickland, D.K.; Bakillah, A. The Mammalian Low-Density Lipoprotein Receptor Family. Annu. Rev. Nutr. 1999, 19, 141-172. https://doi.org/10.1146/annurev.nutr.19.1.141. 171. Mahley, R.W.; Rall, S.C. A POLIPOPROTEIN E: Far More Than a Lipid Transport Protein. Annu. Rev. Genom. Hum. Genet. 2000, 1, 507-537. https://doi.org/10.1146/annurev.genom.1.1.507.

172. Probst, J.; Weide, B.; Scheel, B.; Pichler, B.J.; Hoerr, I.; Rammensee, H.-G.; Pascolo, S. Spontaneous Cellular Uptake of Exogenous Messenger RNA in Vivo Is Nucleic Acid-Specific, Saturable and Ion Dependent. Gene Ther. 2007, 14, 1175-1180. https://doi.org/10.1038/sj.gt.3302964.

173. Lazzaro, S.; Giovani, C.; Mangiavacchi, S.; Magini, D.; Maione, D.; Baudner, B.; Geall, A.J.; De Gregorio, E.; D’Oro, U.; Buonsanti, C. CD8 T-Cell Priming upon MRNA Vaccination Is Restricted to Bone-Marrow-Derived Antigen-Presenting Cells and May Involve Antigen Transfer from Myocytes. Immunology 2015, 146, 312-326. https://doi.org/10.1111/imm.12505.

174. Blakney, A.K.; Deletic, P.; McKay, P.F.; Bouton, C.R.; Ashford, M.; Shattock, R.J.; Sabirsh, A. Effect of Complexing Lipids on Cellular Uptake and Expression of Messenger RNA in Human Skin Explants. J. Control. Release 2021, 330, 1250-1261. https://doi.org/10.1016/j.jconrel.2020.11.033.

175. Ratajczak, J.; Miekus, K.; Kucia, M.; Zhang, J.; Reca, R.; Dvorak, P.; Ratajczak, M.Z. Embryonic Stem Cell-Derived Microvesicles Reprogram Hematopoietic Progenitors: Evidence for Horizontal Transfer of MRNA and Protein Delivery. Leukemia 2006, 20, 847-856. https://doi.org/10.1038/sj.leu.2404132.

176. Skog, J.; Würdinger, T.; van Rijn, S.; Meijer, D.H.; Gainche, L.; Curry, W.T.; Carter, B.S.; Krichevsky, A.M.; Breakefield, X.O. Glioblastoma Microvesicles Transport RNA and Proteins That Promote Tumour Growth and Provide Diagnostic Biomarkers. Nat. Cell Biol. 2008, 10, 1470-1476. https://doi.org/10.1038/ncb1800.

177. Ratajczak, M.Z.; Ratajczak, J. Extracellular Microvesicles/Exosomes: Discovery, Disbelief, Acceptance, and the Future? Leukemia 2020, 34, 3126-3135. https://doi.org/10.1038/s41375-02001041-z.

178. Van den Boorn, J.G.; Schlee, M.; Coch, C.; Hartmann, G. SiRNA Delivery with Exosome Nanoparticles. Nat. Biotechnol. 2011, 29, 325-326. https://doi.org/10.1038/nbt.1830. 
The first preprint version posted on OSF preprints (July 26, 2021). The published version of this preprint is available at [https://www.mdpi.com/20734425/13/5/719] Citation: Domazet-Lošo, T. mRNA Vaccines: Why Is the Biology of Retroposition lgnored? Genes 2022, 13, 719. https://doi.org/10.3390/genes13050719

179. Kowal, J.; Tkach, M. Dendritic Cell Extracellular Vesicles. In International Review of Cell and

Molecular Biology; Elsevier: Amsterdam, The Netherlands, 2019; Volume 349, pp. 213-249. ISBN 978-0-12-818357-1.

180. Ying, W.; Riopel, M.; Bandyopadhyay, G.; Dong, Y.; Birmingham, A.; Seo, J.B.; Ofrecio,

J.M.; Wollam, J.; Hernandez-Carretero, A.; Fu, W.; et al. Adipose Tissue Macrophage-Derived

Exosomal MiRNAs Can Modulate In Vivo and In Vitro Insulin Sensitivity. Cell 2017, 171, 372 384.e12. https://doi.org/10.1016/j.cell.2017.08.035.

181. Ostermeier, G.C.; Miller, D.; Huntriss, J.D.; Diamond, M.P.; Krawetz, S.A. Delivering Spermatozoan RNA to the Oocyte. Nature 2004, 429, 154-154. https://doi.org/10.1038/429154a.

182. Chen, Q.; Yan, W.; Duan, E. Epigenetic Inheritance of Acquired Traits through Sperm RNAs and Sperm RNA Modifications. Nat. Rev. Genet. 2016, 17, 733-743. https://doi.org/10.1038/nrg.2016.106.

183. Sun, Y.H.; Wang, A.; Song, C.; Shankar, G.; Srivastava, R.K.; Au, K.F.; Li, X.Z. SingleMolecule Long-Read Sequencing Reveals a Conserved Intact Long RNA Profile in Sperm. Nat. Commun. 2021, 12, 1361. https://doi.org/10.1038/s41467-021-21524-6.

184. Sciamanna, I.; Serafino, A.; Shapiro, J.A.; Spadafora, C. The Active Role of Spermatozoa in Transgenerational Inheritance. Proc. $\quad$ R. Soc. $\quad$ B. $2019,286,2019$. https://doi.org/10.1098/rspb.2019.1263.

185. Cossetti, C.; Lugini, L.; Astrologo, L.; Saggio, I.; Fais, S.; Spadafora, C. Soma-to-Germline Transmission of RNA in Mice Xenografted with Human Tumour Cells: Possible Transport by Exosomes. PLoS ONE 2014, 9, e101629. https://doi.org/10.1371/journal.pone.0101629.

186. Kim, D.; Lee, J.-Y.; Yang, J.-S.; Kim, J.W.; Kim, V.N.; Chang, H. The Architecture of SARSCoV-2 Transcriptome. Cell 2020, 181, 914-921.e10. https://doi.org/10.1016/j.cell.2020.04.011.

187. Flasch, D.A.; Macia, Á.; Sánchez, L.; Ljungman, M.; Heras, S.R.; García-Pérez, J.L.; Wilson, T.E.; Moran, J.V. Genome-Wide de Novo L1 Retrotransposition Connects Endonuclease Activity with Replication. Cell 2019, 177, 837-851.e28. https://doi.org/10.1016/j.cell.2019.02.050.

188. Sultana, T.; van Essen, D.; Siol, O.; Bailly-Bechet, M.; Philippe, C.; Zine El Aabidine, A.; Pioger, L.; Nigumann, P.; Saccani, S.; Andrau, J.-C.; et al. The Landscape of L1 Retrotransposons in the Human Genome Is Shaped by Pre-Insertion Sequence Biases and Post-Insertion Selection. Mol. Cell 2019, 74, 555-570.e7. https://doi.org/10.1016/j.molcel.2019.02.036.

189. Aldén, M.; Olofsson Falla, F.; Yang, D.; Barghouth, M.; Luan, C.; Rasmussen, M.; De Marinis, Y. Intracellular Reverse Transcription of Pfizer BioNTech COVID-19 MRNA Vaccine BNT162b2 In Vitro in Human Liver Cell Line. CIMB 2022, 44, 1115-1126. https://doi.org/10.3390/cimb44030073. 190. Bartha, I.; di Iulio, J.; Venter, J.C.; Telenti, A. Human Gene Essentiality. Nat. Rev. Genet. 2018, 19, 51-62. https://doi.org/10.1038/nrg.2017.75. 
The first preprint version posted on OSF preprints (July 26, 2021). The published version of this preprint is available at [https://www.mdpi.com/20734425/13/5/719] Citation: Domazet-Lošo, T. mRNA Vaccines: Why Is the Biology of Retroposition lgnored? Genes 2022, 13, 719. https://doi.org/10.3390/genes13050719

191. Zhang, L.; Vijg, J. Somatic Mutagenesis in Mammals and Its Implications for Human Disease and Aging. Annu. Rev. Genet. 2018, 52, 397-419. https://doi.org/10.1146/annurev-genet-120417031501.

192. Sender, R.; Milo, R. The Distribution of Cellular Turnover in the Human Body. Nat. Med. 2021, 27, 45-48. https://doi.org/10.1038/s41591-020-01182-9.

193. Tomasetti, C.; Poling, J.; Roberts, N.J.; London, N.R.; Pittman, M.E.; Haffner, M.C.; Rizzo, A.; Baras, A.; Karim, B.; Kim, A.; et al. Cell Division Rates Decrease with Age, Providing a Potential Explanation for the Age-Dependent Deceleration in Cancer Incidence. Proc. Natl. Acad. Sci. USA 2019, 116, 20482-20488. https://doi.org/10.1073/pnas.1905722116.

194. Pucella, J.N.; Upadhaya, S.; Reizis, B. The Source and Dynamics of Adult Hematopoiesis: Insights from Lineage Tracing. Annu. Rev. Cell Dev. Biol. 2020, 36, 529-550. https://doi.org/10.1146/annurev-cellbio-020520-114601.

195. Hirano, T.; Iwasaki, Y.W.; Lin, Z.Y.-C.; Imamura, M.; Seki, N.M.; Sasaki, E.; Saito, K.; Okano, H.; Siomi, M.C.; Siomi, H. Small RNA Profiling and Characterization of PiRNA Clusters in the Adult Testes of the Common Marmoset, a Model Primate. RNA 2014, 20, 1223-1237. https://doi.org/10.1261/rna.045310.114.

196. Wang, C.; Lin, H. Roles of PiRNAs in Transposon and Pseudogene Regulation of Germline MRNAs and LncRNAs. Genome Biol. 2021, 22, 27. https://doi.org/10.1186/s13059-020-02221-x.

197. Xia, X. Detailed Dissection and Critical Evaluation of the Pfizer/BioNTech and Moderna MRNA Vaccines. Vaccines 2021, 9, 734. https://doi.org/10.3390/vaccines9070734.

198. Pardi, N.; Hogan, M.J.; Weissman, D. Recent Advances in MRNA Vaccine Technology. Curr.

Opin. Immunol. 2020, 65, 14-20. https://doi.org/10.1016/j.coi.2020.01.008.

199. Jain, R.; Frederick, J.P.; Huang, E.Y.; Burke, K.E.; Mauger, D.M.; Andrianova, E.A.; Farlow, S.J.; Siddiqui, S.; Pimentel, J.; Cheung-Ong, K.; et al. MicroRNAs Enable MRNA Therapeutics to Selectively Program Cancer Cells to Self-Destruct. Nucleic Acid Ther. 2018, 28, 285-296. https://doi.org/10.1089/nat.2018.0734.

200. Jiang, H.; Mei, Y.-F. SARS-CoV-2 Spike Impairs DNA Damage Repair and Inhibits V(D)J Recombination In Vitro. Viruses 2021, 13, 2056. https://doi.org/10.3390/v13102056.

201. Finlay, B.B.; Amato, K.R.; Azad, M.; Blaser, M.J.; Bosch, T.C.G.; Chu, H.; Dominguez-Bello, M.G.; Ehrlich, S.D.; Elinav, E.; Geva-Zatorsky, N.; et al. The Hygiene Hypothesis, the COVID Pandemic, and Consequences for the Human Microbiome. Proc. Natl. Acad. Sci. USA 2021, 118, e2010217118. https://doi.org/10.1073/pnas.2010217118.

202. Romano-Keeler, J.; Zhang, J.; Sun, J. COVID-19 and the Neonatal Microbiome: Will the Pandemic Cost Infants Their Microbes? Gut Microbes 2021, 13, 1912562. https://doi.org/10.1080/19490976.2021.1912562. 
The first preprint version posted on OSF preprints (July 26, 2021). The published version of this preprint is available at [https://www.mdpi.com/20734425/13/5/719] Citation: Domazet-Lošo, T. mRNA Vaccines: Why Is the Biology of Retroposition Ignored? Genes 2022, 13, 719. https://doi.org/10.3390/genes13050719

203. Ghanemi, A.; Yoshioka, M.; St-Amand, J. Coronavirus Disease 2019 (COVID-19) Crisis: 1222 Losing Our Immunity When We Need It the Most. Biology 2021, 10, 545.1223 https://doi.org/10.3390/biology10060545. 1224

204. Feliciello, I.; Procino, A. MRNA Vaccines: Why and How They Should Be Modified. J. Biol. 1225 Res. 2021, 94, 10072. https://doi.org/10.4081/jbr.2021.10072. 1226

205. Adams, J.W.; Kaufman, R.E.; Kretschmer, P.J.; Harrison, M.; Nienhuis, A.W. A Family of 1227 Long Reiterated DNA Sequences, One Copy of Which Is next to the Human Beta Globin Gene. Nucl. 1228 Acids Res. 1980, 8, 6113-6128. https://doi.org/10.1093/nar/8.24.6113. 1229

206. Skowronski, J.; Singer, M.F. Expression of a Cytoplasmic LINE-1 Transcript Is Regulated in 1230 a Human Teratocarcinoma Cell Line. Proc. Natl. Acad. Sci. USA 1985, 82, 6050-6054. 1231 https://doi.org/10.1073/pnas.82.18.6050. 1232

207. Dong, Y.; Sun, F.; Ping, Z.; Ouyang, Q.; Qian, L. DNA Storage: Research Landscape and 1233 Future Prospects. Natl. Sci. Rev. 2020, 7, 1092-1107. https://doi.org/10.1093/nsr/nwaa007. 1234 208. European Medicines Agency. Comirnaty: EPAR—Product Information. 2021. Available 1235 online: https://www.ema.europa.eu/en/documents/product-information/comirnaty-epar-product- 1236 information_en.pdf (accessed on 27 January 2021). 1237 209. European Medicines Agency. Spikevax (Previously COVID-19 Vaccine Moderna): EPAR— 1238 Product Information. 2021. Available online: https://www.ema.europa.eu/en/documents/product- 1239 information/spikevax-previously-covid-19-vaccine-moderna-epar-product-information_en.pdf 1240 (accessed on 28 January 2021). 1241 